\title{
Taxonomy, distribution and habitats of the Dytiscidae (Coleoptera) of Ethiopia
}

\author{
Anders N. Nilsson \& Sven Persson
}

Nilsson, A. N. \& Persson, S. 1993: Taxonomy, distribution and habitats of the Dytiscidae (Coleoptera) of Ethiopia. — Entomol. Fennica 4:57-94.

The 168 species of Dytiscidae known from Ethiopia are listed. For each species are given: original citation, synonyms, gross distribution, and distribution in Ethiopia with special reference to altitude and provinces. Besides literature records and museum specimens, 7300 individuals of 53 species collected by the junior author chiefly in the Arssi highlands in 1988 and 1989 are reported on. One syn. n. is presented: Rhantus longulus Régimbart, $1895=$ Rhantus flavicollis Régimbart, 1887. Most of the 38 species endemic to Ethiopia occur only over $2000 \mathrm{~m}$ a.s.l., and the proportion of endemic species is highest in the Gondar, Shoa, Arssi and Bale provinces. The fauna of most provinces is poorly known. The Shoa province is best known, with 92 species recorded. In the Arssi highlands, the maximum local diversity was near 20 species in both lentic and lotic biotopes. The species richness of different supraspecific taxa is discussed and information is presented on co-occurrence of congeneric species and proportions of rare and frequent species.

Anders N. Nilsson, Department of Animal Ecology, University of Umeå, S90187 Umeå, Sweden

Sven Persson, Storgatan 29, S-261 31 Landskrona, Sweden

\section{Introduction}

In 1988 and 1989 the junior author lived in Ethiopia for long periods and collected 7300 specimens of 53 species of dytiscid water beetles. Most of the studied localities were situated near Asella in the Arssi province (22 sites from 1800 to $3100 \mathrm{~m}$ a.s.1.), but a few sites in the Shoa (8, 950-2600), Bale (4, 2050-3450) and Sidamo (1, $1600)$ provinces were also studied. Six of the localities are shown on Figs. 1-6. The senior author is responsible for the identification of this material in cooperation with other specialists, and has prepared the manuscript. Instead of only reporting our material we have found it useful to give a more comprehensive review of the dytiscid fauna of Ethiopia. Such a review has never been published before, and the most inclusive work has long been Omer-Cooper's (1931) report on the large material collected by the Hugh Scott Expedition (Omer-Cooper 1930) to the Shoa and Arssi provinces. The revisions of the Afrotropical Dytiscidae by Régimbart (1895a) and Guignot (1959a, b, 1961) provide broad overviews also of the Ethiopian fauna, but give little detailed information on species distributions within Ethiopia. More recent revisions of several genera (e.g. Biström 1982, 1985, 1986a, 1988a, b) have revealed the incomplete state of knowledge of the fauna and the need for modern treatments in order to make species identification possible. 

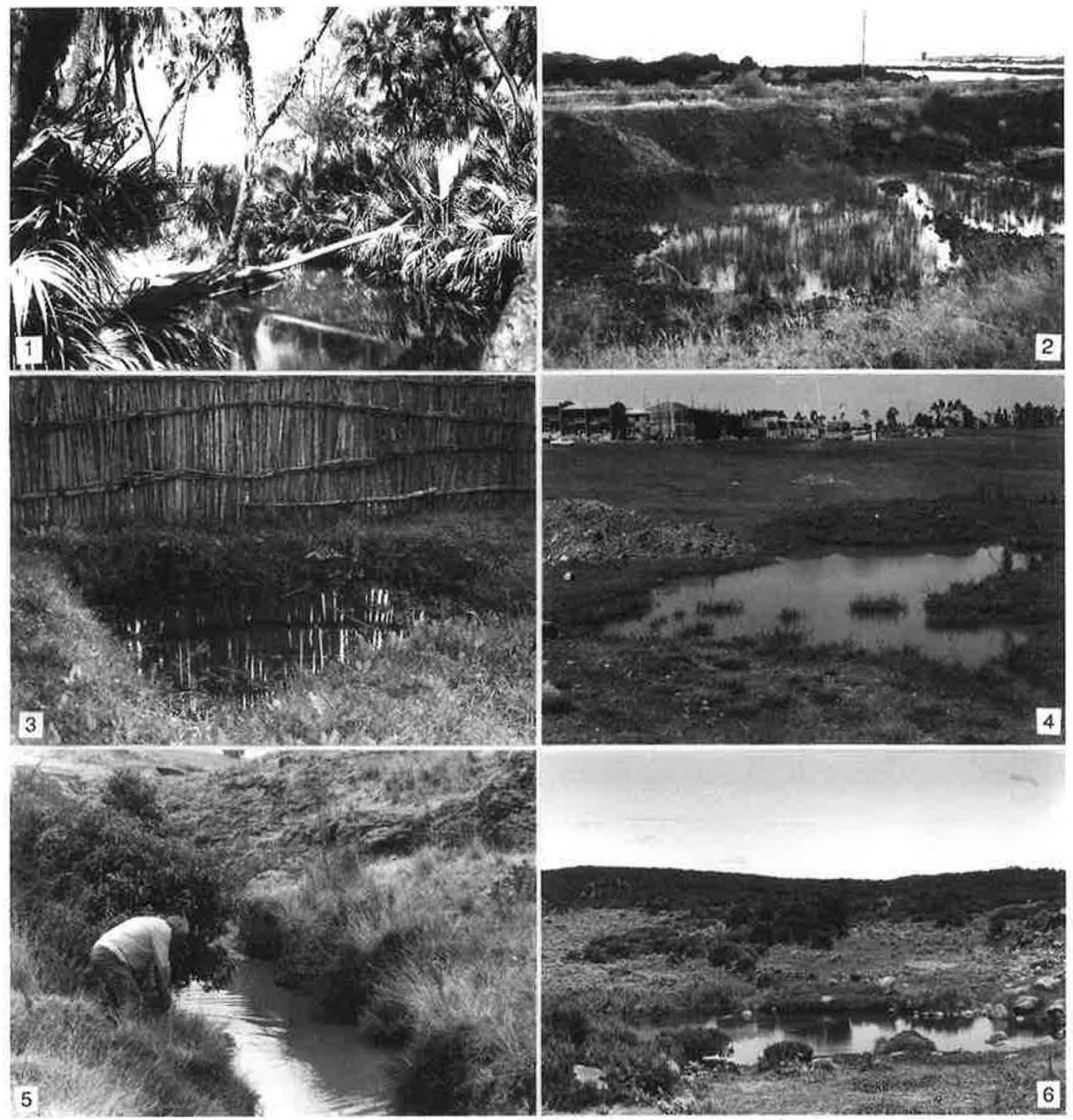

Figs. 1-6. Some habitats of dytiscid water beetles in Ethiopia sampled by the junior author. - 1. Shoa, Awash National Park, Filwoha hot springs, $1500 \mathrm{~m}$ a.s.l., 25.xii.1988. Clear water almost devoid of vegetation and near $50^{\circ} \mathrm{C}$. Hydroglyphus infirmus, $H$. signatellus (dominant) and Laccophilus taeniolatus were found among roots at the margin. - 2. Shoa, Metahara, lava field, $950 \mathrm{~m}$ a.s.l., 24.xii.1988. Pond with emergent vegetation and the following species: Hydroglyphus shalensis, Hydrovatus sordidus, Hyphydrus impressus, Laccophilus taeniolatus, Eretes sticticus, Rhantaticus congestus, Hydaticus basicollis and Cybister tripunctatus africanus. - 3. Bale, Ginir, 2050 m a.s.I., 2.xi.1988. Man-made detritus pool with Hydroglyphus sordidus, Hyphydrus signatus and Hydaticus galla. - 4. Shoa, Addis Ababa, $2350 \mathrm{~m}$ a.s.I., 23.x.1988. Sparsely vegetated temporary pools with the following species: Hydroglyphus sordidus, H. fufai, Hyphydrus puncticollis, H. signatus, Copelatus atrosulcatus, C. erichsoni, C. ragazzii, Rhantus capensis, R. longulus, Laccophilus vitshumbii, L. quindecimvittatus and Hydaticus galla. 5. Arsi, $13 \mathrm{~km}$ S of Asella, $2600 \mathrm{~m}$, 4.ii.1989. Permanent stream with vegetated margins and partly gravelly bottom. Species found were: Bidessus muluensis, Hydroglyphus fufai, H. milkoi, H. sordidus, Uvarus andreinii, Herophydrus muticus, Hyphydrus puncticollis, $H$. signatus, Nebrioporus abyssinicus, N. tellinii, Copelatus ragazzii, Agabus pallidus, A. raffrayi, Rhantus capensis, R. Iongulus, Laccophilus quindecimvittatus, Hydaticus abyssinicus, H. galla. - 6. Arssi, $13 \mathrm{~km}$ E of Bekoji, Galama Mts., $3100 \mathrm{~m}$ a.s.I., 12.xi.1988. Small, shallow lake with highly variable amplitude. Species found were: Hyphydrus puncticollis, Nebrioporus abyssinicus, N. tellinii, Agabus pallidus, Rhantus capensis, R. Iongulus and Hydaticus abyssinicus. Photographs: S. Persson. 


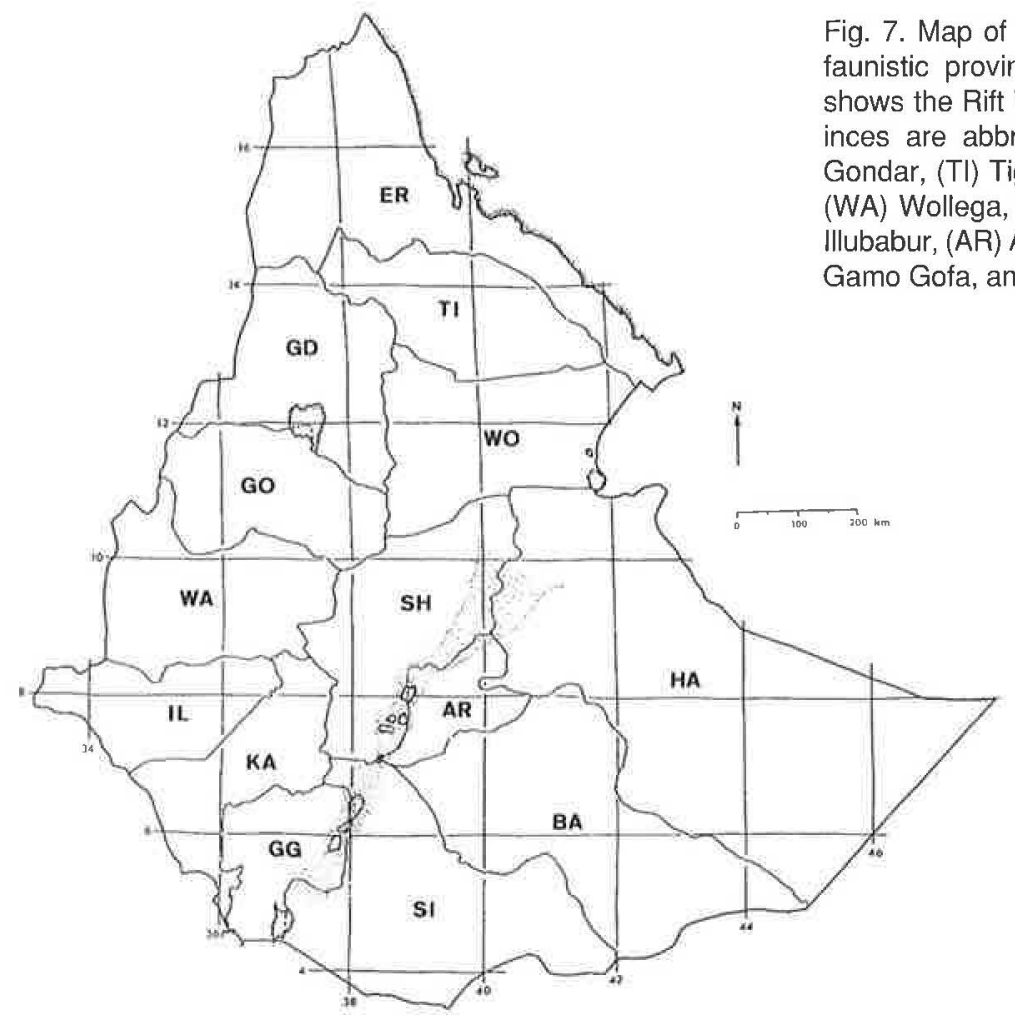

Larger materials of Ethiopian Dytiscidae were first collected by Raffray (1885), Ragazzi, Tellini and Rothschild (Sharp 1882, Régimbart 1887, 1905, 1922), and later by Scott (Omer-Cooper 1930, 1931, Scott 1952, 1958). In the late sixties and early seventies many dytiscids were collected with lighttraps, e.g. at Bahar Dar in the Gojjam province, at Gambela in Illubabur, at Jimma in Kaffa and at Addis Ababa in Shoa (coll. Brancucci, coll. Wewalka, MZH, SMNS, MRAC). A very interesting material (in coll. MZH) was collected in highaltitude running waters by Harrison \& Hynes (1988), who also provided a general description of these environments and a discussion of biogeography of Ethiopian aquatic insects. The Ethiopian highlands and their insect fauna were described by Mani (1968).

The faunistic provinces of Ethiopia are delimited and abbreviated as in Fig. 7. We use "Ethiopian" as referring to the country of Ethiopia.

The following museum abbreviations are used:

MRAC Royal Museum of Central Africa, Tervuren,
MZH Museum Zoologicum, Helsinki,

SMNS National Museum of Natural History, Stuttgart.

The material collected by the junior author is split between the collections of the authors and the Entomological University Museum, Lund (LUM).

In order to use a correct nomenclature all original descriptions of species and genera were examined. At least single specimens were examined of almost all of the 168 species known from Ethiopia.

\section{Ethiopian Dytiscidae}

\section{Subfamily Hydroporinae Erichson, 1837}

Genus Canthyporus Zimmermann, 1919

A small genus confined to Africa. Most of the about 30 described species are restricted to South Africa (Omer-Cooper 1965a), and only 
six species occur in the Central African mountains. Our treatment of the genus follows Wewalka (1981) and Nilsson (1991a), who described the two species known from Ethiopia.

\section{Canthyporus loeffleri Wewalka}

Canthyporus loeffleri Wewalka, 1981: 61, 62 + figs. 5, 9.

A rare species known only from the type locality, i.e. GD:Simien Mts. at $3500 \mathrm{~m}$ a.s.1. This species is endemic to Ethiopia.

\section{Canthyporus hynesi Nilsson}

Canthyporus hynesi Nilsson, 1991a:183-185.

A rare species known only from the type locality, i.e. a tributary to the Dima River at 2,850 $\mathrm{m}$ a.s.l. in Shoa. This species is endemic to Ethiopia.

\section{Genus Methles Sharp, 1882}

A small genus known from the southernmost Palaearctic, Ethiopian and Oriental Regions (Franciscolo 1966). Guignot (1959a) recognized four species in Africa, and the male genitalia of three of them were illustrated by Bilardo \& Rocchi (1987:93, figs. 3-5). The genus is in need of a revision.

\section{Methles cribratellus (Fairmaire)}

Hydroporus cribratellus Fairmaire, 1880: 248.

Methles punctipennis Sharp, 1882: $490+$ pl. 13:162.

Methles umbrosus Gschwendtner, 1930: 210.

Methles cribratellus sparsepunctatus Guignot, 1956a: 75.

A widespread species in Africa, known from Algeria to South Africa (Omer-Cooper 1965a). In Ethiopia known from the extreme south, GG:Namuruputh, Lake Turkana, $565 \mathrm{~m}$ a.s.l., 25-30.i.1933 (Guignot 1936:8) to SH:Addis Ababa (leg. Brancucci 1969, at light). Specimens from IL and KA were seen in MRAC.

\section{Methles spinosus Sharp}

Methles spinosus Sharp, 1882: 489, 490.

This species occurs in Syria and in Africa from Egypt to Botswana (Guignot 1959a:56,
Bilardo \& Rocchi 1987:92). The only Ethiopian record is from GG:Namuruputh at $565 \mathrm{~m}$ a.s.l. by the Lake Turkana (Guignot 1936:9).

\section{Genus Derovatellus Sharp, 1882}

A relatively small genus with 33 species described from Africa, America and Borneo. The 28 African species were revised by Biström (1979). A single species is known from Ethiopia.

\section{Derovatellus bisignatus Ahlwarth}

Derovatellus bisignatus Ahlwarth, 1921: 442.

Derovatellus nyasaensis Omer-Cooper, 1958: 250.

An East African species known from Kenya, Tanzania, Zaire, Uganda, Malawi, Ethiopia and Sudan (Biström 1979, 1986b). The single Ethiopian record is from IL:Gambela, 27.vii.1972 (Biström 1979:16).

\section{Genus Uvarus Guignot, 1939}

A widely distributed genus with $50-60$ species. Of the 35 African species, only five occur in Ethiopia (Biström 1988a).

\section{Uvarus andreinii (Régimbart)}

Bidessus andreinii Régimbart, 1905: 206.

This species is probably endemic to Ethiopia as previous records from other countries have not been verified (Biström 1988a:8). It was described from ER, and later reported from SH:Addis-Ababa, GO, IL and GD (Régimbart 1922; confirmed by Biström, pers. comm.). Additional records from altitudes between 1500 and $2500 \mathrm{~m}$ a.s.l. in SH were provided by OmerCooper (1931:769).

In our material, $U$. andreinii is represented only from two sites in AR, where it seemingly belongs to the rarer species. At Asella it was found in a man-made forest pond at $2350 \mathrm{~m}$ a.s.l., and $13 \mathrm{~km}$ $\mathrm{S}$ of Asella it occurred among gravel in a permanent river at $2600 \mathrm{~m}$ a.s.l. (Fig. 5).

\section{Uvarus peringueyi (Régimbart)}

Bidessus peringueyi Régimbart, 1895a: 84.

Bidessus galla Régimbart, 1895a: 81.

This species is distributed from Ethiopia to South Africa (Biström 1988a:9). It was described 
as $B$. galla by Régimbart (1895a, b) from AR:Ganale Gudda. Later found at KA:Gojeb valley (Biström unpubl.).

\section{Uvarus captiosus (Guignot)}

Amarodytes captiosus Guignot, 1948: 2.

Biström (1988a:16) recorded this species from Sudan, Ethiopia, Zaire, Uganda, Kenya, Tanzania, Angola and possibly also Malawi. The two Ethiopian records are from SH:Addis Ababa and IL:Gambela (Biström pers. comm. \& coll. Hendrich).

\section{Uvarus devroyei (Gschwendtner)}

Bidessus devroyei Gschwendtner, 1932: 261.

Bidessus bredoi Gschwendtner, 1943: 424.

Amarodytes baoulicus bicolor Guignot, 1948: 4.

Uvarus melanopterus Guignot, 1959c: 150.

Uvarus garambanus Bruneau de Miré \& Legros, 1963: 869.

Widespread in Africa from Chad to South Africa (Biström 1988a:22). The Ethiopian records presented by Biström (l.c.) are from KA and $\mathrm{SH}$ (Biström unpubl.), and an additional specimen from IL:Gambela was seen in coll. Hendrich.

\section{Uvarus miser Bilardo \& Pederzani}

Uvarus miser Bilardo \& Pederzani, 1979: 769.

This species is known from Ethiopia, Kenya and Uganda in East Africa (Biström 1988a:31). In Ethiopia it is only known from the type locality at SH:Gibbie Gorge, where it was collected in 1971 at about $1100 \mathrm{~m}$ a.s.1.

\section{Genus Pseuduvarus Biström, 1988}

A monobasic genus confined to the Ethiopian and Oriental Regions (Nilsson \& Wewalka unpubl.).

\section{Pseuduvarus vitticollis (Boheman)}

Hydroporus vitticollis Boheman, 1848: 256.

Bidessus octoguttatus Régimbart, 1895a: 94.

Bidessus ornatipennis Régimbart, 1899: 372.

Amarodytes octoguttatus caligosus Guignot, 1946: 254, 257.

Uvarus monticola Guignot, 1957: 98.
Widespread in Africa south of Sahara (Biström 1988c:11-12). It was described from Ethiopia by Régimbart (1895a) as B. octoguttatus. More recent records from this country are from IL and KA (Biström unpubl.).

Genus Hydroglyphus Motschulsky, 1853

A relatively large genus with some 80 species in Europe, Asia, Australia and Africa (Biström 1988c:12). Our treatment follows Biström's (1986a) revision of the 41 African species, with a later addition (Biström \& Nilsson 1990). Sixteen species have so far been recorded from Ethiopia.

\section{Hydroglyphus infirmus (Boheman)}

Hydroporus infirmus Boheman, 1848: 251.

Bidessus geminus var. capensis Régimbart, 1894: 234.

Guignotus marmottani Guignot, 1940: 33.

This species is widespread in East and South Africa, and occurs also in South Arabia (Biström 1986a:9-10). It was recorded from Asmara, AdiUgri and Keren in ER by Régimbart (1905), and from GD and HA by Régimbart (1922). OmerCooper (1931:771, as B. capensis) presented several records from AR and SH between 1700 and $2300 \mathrm{~m}$ a.s.1. Later, it has also been collected in GO, WO, BA and SI (Biström unpubl.).

In our material it is one of the less frequently collected species with 14 specimens from five localities: three in AR (1800-2500 m a.s.1.) and two in SH (1500 m a.s.1.). Most specimens were found in small stagnant waters with no or little vegetation, also in a hot spring (Fig. 1).

\section{Hydroglyphus confusus (Klug)}

Hydroporus confusus Klug, 1834: tab. 34, fig. 4.

This species is widespread in the northern half of Africa and in Arabia (Biström 1986a:1011). It was recorded from ER:Asmara and Saganeiti by Régimbart (1905), and later (Régimbart 1922) from SH:Filwoha. Several records from between 1500 and $2300 \mathrm{~m}$ a.s.l. in $\mathrm{AR}$ and $\mathrm{SH}$ were presented by Omer-Cooper (1931:772). Additional records are from Biström (unpubl.), also from HA. 
Hydroglyphus geminodes (Régimbart)

Bidessus geminodes Régimbart, 1895a: 88.

Bidessus africanus Régimbart, 1895a: 90.

This species occupies most of Africa south of the Sahara (Biström 1986a:11-13). From Ethiopia, it was recorded from between 1500 and 2300 $\mathrm{m}$ a.s.l. in SH by Omer-Cooper (1931:773). Additional records from ER, IL, KA and GG were provided by Biström (unpubl.).

\section{Hydroglyphus shalensis (Omer-Cooper)}

Bidessus shalensis Omer-Cooper, 1931: $770+$ pl. 8:3.

This species was described from Ethiopia, where it first was found in a small pond near Lake Shala at $1500 \mathrm{~m}$ a.s.l. in SH (Omer-Cooper 1931). Later it has been found also in Kenya and Tanzania (Biström 1986a:14-15), and in Ethiopia at $1350 \mathrm{~m}$ a.s.l. in SI (Biström unpubl.).

A single female that probably belongs to this species was found in a lava-field pool near SH:Metahara, at $950 \mathrm{~m}$ a.s.l., 2.x.1988 (Fig. 2).

\section{Hydroglyphus aethiopicus (Régimbart)}

Bidessus geminus var. aethiopicus Régimbart, 1907: 127. Guignotus abyssinicus Guignot, 1940: 32.

This species is widely distributed in East Africa from Ethiopia to South Africa (Biström 1986a:16). It was first described by Régimbart (1907) from SH. Omer-Cooper (1931) did not separate $H$. aethiopicus from $H$. geminodes, and some of her specimens from SH:Hora Bishoftu were later described by Guignot (1940) as $G$. abyssinicus. Omer-Cooper (1931) also had $H$. aethiopicus from Hora Harsadi, Hora Horeso and Hora Shala (Biström unpubl.). More recent records are from KA and SI (Biström unpubl.).

\section{Hydroglyphus milkoi (Omer-Cooper)}

Bidessus milkoi Omer-Cooper, 1931: 775, 776 + pl. 8:5.

This species is endemic to Ethiopia (Biström 1986a:20). It was described from a large number of localities in $\mathrm{AR}$ and $\mathrm{SH}$, ranging from 1500 to $2500 \mathrm{~m}$ a.s.l. (Omer-Cooper 1931). Later also collected in WO (Biström unpubl.), and at light at GO:Bahar Dar (SMNS).
This is one of the commonest species in our material, with a total sum of 637 specimens. Most specimens are from AR, where $H$. milkoi was collected from 2350 to $3100 \mathrm{~m}$ a.s.l. It was also found at single sites in $\mathrm{BA}$ and $\mathrm{SH}$, at 3100 and $2600 \mathrm{~m}$ a.s.l., respectively. H. milkoi was equally common in both stagnant and running waters (Figs. 5, 6), but confined to pools in the latter kind.

\section{Hydroglyphus pentagrammus (Schaum)}

Hydroporus pentagrammus Schaum, 1864: 106, 108.

This species is known from Egypt, Sudan and Ethiopia (Biström 1986a:26). A long series was collected at light near SH:Addis Ababa in 1969 (Biström unpubl.), and a single specimen from IL:Gambela was seen in coll. Hendrich.

\section{[Hydroglyphus transvaalensis (Régimbart)}

Bidessus confusus var. transvaalensis Régimbart, 1894: 234.

This species is widespread in East and South Africa (Biström 1986a:33). It was listed from Ethiopia with a question-mark by Guignot (1959a:278), and this record was later cited by Omer-Cooper (1965a:122). As Biström (1986a) could not confirm the occurrence of this species in Ethiopia, it has probably never been found there.]

\section{Hydroglyphus flavoguttatus (Régimbart)}

Bidessus flavoguttatus Régimbart, 1895a: 93.

Bidessus longipilis Régimbart, 1895a: 94.

Guignotus desertorum Guignot, 1955a: 862.

This species is widespread in Africa south of the Sahara (Biström 1986a:34-35). The only Ethiopian record was presented by Biström (1.c.), who had examined a single specimen from SH:Addis Ababa, taken at light in 1969 (Biström unpubl.).

\section{Hydroglyphus major (Sharp)}

Bidessus major Sharp, 1882: 354.

Bidessus major sellatus Peyerimhoff, 1931: 20.

This species occurs in Iran, Arabia and northeast Africa. In Africa known chiefly from 
the Red Sea coast and central Sahara (Biström 1986a:39). The only Ethiopian record is from ER:Adi Ugri (Biström unpubl.).

\section{Hydroglyphus angularis (Klug)}

Hydroporus angularis Klug, 1834: tab. 34, figs. 1, 2. Hydroporus klugii Leprieur, 1880: XXV.

This species is widespread in the northern half of Africa (Biström 1986a:44), and occurs also in Saudi Arabia (Brancucci 1984). It was reported from Asmara and Saganeiti in ER by Régimbart (1905:206), and here also collected at Setit Humera in 1973 (Biström unpubl.).

\section{Hydroglyphus angulolineatus (Guignot)}

Guignotus angulolineatus Guignot, 1956b: 252.

This species is known from Chad and East Africa (Biström 1986a:44, 45). Some Ethiopian records from $\mathrm{SH}$ and SI were mapped by Biström (l.c.), but lost from the accompanying text by mistake (Biström in litt.). In SI collected near hot spring at Noikein at $1350 \mathrm{~m}$ a.s.l. in 1972 (Biström unpubl.).

\section{Hydroglyphus perssoni Biström \& Nilsson}

Hydroglyphus perssoni Biström \& Nilsson, 1990: $181+$ figs. $1-4$.

This species is endemic to Ethiopia. It is known only from the type locality; a sparsely vegetated pond $10 \mathrm{~km} \mathrm{~N}$ of Dinsho at $2800 \mathrm{~m}$ a.s.l. in BA.

\section{Hydroglyphus sordidus (Sharp)}

Bidessus sordidus Sharp, 1882: 355.

Guignotus sordidus robustus Omer-Cooper, 1959: 127.

An East African species known from Ethiopia to Malawi (Biström 1986a:47). It was described by Sharp (1882) from Ethiopia, and later reported by Régimbart (1905) from several localities in ER. Other records given by Régimbart (1887, 1922) from Ethiopia refer partly to other species. Omer-Cooper (1931:774) gave several records from $\mathrm{AR}$ and $\mathrm{SH}$, ranging in altitude from 1500 to $2500 \mathrm{~m}$ a.s.l. Later also collected in $\mathrm{BA}, \mathrm{GG}$ and SI down to $1200 \mathrm{~m}$ a.s.l. (Biström unpubl.).
We have 481 specimens of $H$. sordidus from 12 localities, chiefly in AR, where it was collected from 2350 to $2600 \mathrm{~m}$ a.s.1. The two sites in BA were at 2050 and $3100 \mathrm{~m}$ a.s.1., respectively. In SH it was found in high numbers at $2350 \mathrm{~m}$ a.s.l. In spite of its presence in both running and stagnant waters, $H$. sordidus was only abundant in smaller stagnant waters (Figs. 3-5).

\section{Hydroglyphus fufai (Omer-Cooper)}

Bidessus fufai Omer-Cooper, 1931: $774+$ pl. 7:1.

This species is endemic to Ethiopia. It was first described from SH:Fallé by Régimbart (1887) as an unnamed variety of $H$. sordidus. Omer-Cooper (1931) recognized the status as a separate species, which she described from several localities in $\mathrm{SH}$, at altitudes from 2300 to $2700 \mathrm{~m}$ a.s.1. It was later reported by Rocchi (1975a) from SH:Bargà at $2069 \mathrm{~m}$ a.s.l., and Harrison \& Hynes (1988) collected it at $3000 \mathrm{~m}$ a.s.l. near Addis Ababa. Known also from GD and IL (Biström unpubl.).

In our material, $H$. fufai is represented by 504 specimens from 16 localities. Most specimens are from AR, collected at 2350 to $3100 \mathrm{~m}$ a.s.l. Two sites each in BA and SH were all within this altitudinal range. $H$. fufai was frequently collected in both stagnant and running waters (Figs. 4-6).

\section{Hydroglyphus zanzibarensis (Régimbart)}

Bidessus geminodes var. zanzibarensis Régimbart, 1906: 246.

Bidessus orarius Omer-Cooper, 1931: 772.

This species is widely distributed in South and East Africa (Biström 1986a:49). It was first recorded from Ethiopia by Capra (1952) from GO:Gorgorà by Lake Tana, and Biström (1986a:49) mapped additional records from IL, GG and SI.

\section{Hydroglyphus signatellus (Klug)}

Hydroporus signatellus Klug, 1834: tab. 34, fig. 3. Hydroporus thermalis Germar, 1838: tab. 3.

This species is in Africa known from mainly coastal regions from Senegal to Kenya (Biström 
1986a:51). It was first reported from Ethiopia by Régimbart (1887) from Mt. Wann in SH. Additional records are from HA: Kelafo and the Sagan River (Biström unpubl.).

We have this species only from the Filwoha hot springs in the Awash natn. park at $1500 \mathrm{~m}$ a.s.1. in SH. It was here abundant in clear water of about $50^{\circ} \mathrm{C}$ with almost no vegetation (Fig. 1.).

\section{Genus Bidessus Sharp, 1882}

A Palaearctic and African genus with 46 species. The 30 species of the Ethiopian Region belong to the group $B$. sharpi that was revised by Biström (1985). With a later addition (Biström \& Nilsson 1990), nine species are known from Ethiopia.

\section{Bidessus sharpi Régimbart}

Bidessus sharpi Régimbart, 1895a: 77.

Bidessus sharpi nigeriensis Omer-Cooper, 1974: 306, 307. Bidessus sharpi sudanensis Omer-Cooper, 1974: 306, 307. Bidessus sedilloti Régimbart, 1895a: 78.

Bidessus granulum Régimbart, 1895a: 79.

Bidessus fictor Omer-Cooper, 1959: 124.

This species has a wide distribution in Africa south of the Sahara, with an isolated occurrence in Tunisia (Biström 1985:10). The single Ethiopian record is from IL:Gambela (Biström 1985:8).

\section{Bidessus complicatus Sharp}

Bidessus complicatus Sharp, 1901: 4.

Bidessus brevistriga Régimbart, 1906: 245.

Bidessus ghesquierei Guignot, 1948: 1.

This species is widely distributed in Central Africa south to Malawi and Botswana, with an isolated record from Egypt (Biström 1985:13, Bilardo \& Rocchi 1987:100). Omer-Cooper (1931:766) presented some Ethiopian records from $\mathrm{SH}$. Also recorded from Ethiopia by Biström (1984a).

\section{Bidessus cacozelus Omer-Cooper}

Bidessus cacozelus Omer-Cooper, 1931: $767+$ pl. 7:2. Bidessus cacozelus londianiensis Guignot, 1945: 8.

Bidessus fallax Guignot, 1945: 8.

Bidessus fallax ugandensis Omer-Cooper, 1979: 198, 206.
This is an East African species, with certainty known from Ethiopia, Kenya, Uganda and Tanzania (Biström 1985:22). It was first described from Ethiopia, Wouramboulchi at $2700 \mathrm{~m}$ a.s.1. in SH (Omer-Cooper 1931), and in the same material found also at $1800-2100 \mathrm{~m}$ a.s.1. (Biström 1985:22).

\section{Bidessus perssoni Biström \& Nilsson}

Bidessus perssoni Biström \& Nilsson, 1990: 183 + figs. 5-8.

This species is endemic to Ethiopia. So far, it is known only from the type locality in Galema Mts. $13 \mathrm{~km}$ E of Bekoji at $3100 \mathrm{~m}$ a.s.1., AR. B. perssoni was found in a stream dewatering a small lake (Fig. 6).

\section{Bidessus ovoideus Régimbart}

Bidessus ovoideus Régimbart, 1895a: 81.

This species has a wide distribution in East Africa, where it is known from Ethiopia to South Africa (Biström 1985:27-28). Known also from Cameroon (Biström \& Sanfilippo 1986). It was first reported from Ethiopia by Omer-Cooper (1931:766), who listed this species from 14 sites in $\mathrm{AR}$ and $\mathrm{SH}$, ranging in altitude from 1500 to $2500 \mathrm{~m}$ a.s.1. Additional records were presented by Biström (1985:26),

This species is in our material represented by 18 specimens from two sites at $2500-2600 \mathrm{~m}$ a.s.l. in AR. It was here found in richly vegetated streams.

\section{Bidessus toumodiensis Guignot}

Bidessus toumodiensis Guignot, 1939: 54. Bidessus festivus Guignot, 1959d: 228.

This species has a wide distribution in Africa south of the Sahara (Biström 1985:31). The only Ethiopian record is from GO:Bahar Dar (Biström 1988d).

\section{Bidessus sodalis Guignot}

Bidessus sodalis Guignot, 1939: 54.

This species has a wide distribution in Africa south of the Sahara, with the southernmost record from Malawi (Biström 1985). The single Ethio- 
pian record is from SH:Addis Ababa (Biström 1984a).

\section{Bidessus rothschildi Régimbart}

Bidessus rothschildi Régimbart, 1907: 126, 127.

Besides a single female of uncertain identity from South Africa, this species is known only from Ethiopia (Biström 1985:34). It was first described from Ouardji (= Wondji ?) and Goro in SH (Régimbart 1907). Later, Omer-Cooper (1931:766) presented additional records from between 1500 and $2300 \mathrm{~m}$ a.s.l. in SH. Finally, Biström (1985:34) listed more recent records from many provinces.

\section{Bidessus muluensis Omer-Cooper}

Bidessus muluensis Omer-Cooper, 1931: 767, $768+\mathrm{pl}$ $7: 3$.

This species is endemic to Ethiopia (Biström 1985:36-37). It was described from four localities between 2100 and $2400 \mathrm{~m}$ a.s.1. in AR and SH (Omer-Cooper 1931:768). Additional records were given by Biström (1985:36), including a record from $2950 \mathrm{~m}$ a.s.l. in the Simien Mts.

B. muluensis is in our material represented by 115 specimens from four sites between 2350 and $2600 \mathrm{~m}$ a.s.1. in AR. All records were from streams and rivers (Fig. 5).

\section{Genus Leiodytes Guignot, 1936}

A small genus with 19 species, of which seven occur in Africa (Biström 1987). Of these, only two species have been found in Ethiopia according to Biström's (1987) revision of the African species.

\section{Leiodytes hieroglyphicus (Régimbart)}

Clypeodytes hieroglyphicus Régimbart, 1894: 230.

Clypeodytes lautus Régimbart, 1895a: 64.

Clypeodytes ovatus Omer-Cooper, 1931: $765+$ pl. 7:5.

Clypeodytes inumbratus Guignot, 1936: 20.

Clypeodytes ignobilis Omer-Cooper, 1965a: 125, 126.

This species is widely distributed in Africa south of the Sahara (Biström 1987:96). It was described from Ethiopia as $C$. ovatus by OmerCooper (1931:765), who recorded it from Katarr
River near Lake Zwai at $1800 \mathrm{~m}$ a.s.l. in AR. Later collected also at IL:Gambela (Biström unpubl.).

\section{Leiodytes evanescens (Boheman)}

Hydroporus evanescens Boheman, 1848: 252.

Clypeodytes neumanni Régimbart, 1906: 242.

Clypeodytes distinctus J. Balfour-Browne, 1947: 135.

Clypeodytes virgatus Guignot, 1959c: 144.

This species has a wide distribution in Africa south of the Sahara (Biström 1987:96). The only Ethiopian record is from near Kelafo in HA (Biström unpubl.).

\section{Genus Clypeodytes Régimbart, 1894}

The African species of this genus were revised by Biström (1988b), who recognized 24 species in Africa. Some additional 13 species occur in Asia and Australia. Only two species have been found in Ethiopia.

\section{Clypeodytes cribrosus (Schaum)}

Hydroporus cribrosus Schaum, 1864: 106, 107.

Many older records of this species are unreliable and those verified by Biström (1988b:212, 213) show a distribution restricted to Egypt and a narrow belt south of the Sahara. Old Ethiopian records given by Régimbart (1905) and OmerCooper (1931) actually refer to C. meridionalis. Consequently, only two females from GO:Bahar Dar are known from Ethiopia (Biström 1.c.). As the identification of females is uncertain, it is not sure that the species occurs in Ethiopia.

\section{Clypeodytes meridionalis Régimbart}

Clypeodytes meridionalis Régimbart, 1895a: 63. Clypeodytes seminulum Régimbart, 1895a: 63. Clypeodytes cribrosus var. voiensis Guignot, 1936:24.

This species has a wide distribution in Africa south of the Sahara (Biström 1988b:221). It was first recorded from Ethiopia by Régimbart (1905) as C. cribrosus from ER. Omer-Cooper (1931: $765)$ presented additional records from 1800 to $2300 \mathrm{~m}$ a.s.l. in AR and SH, also as C. cribrosus. Besides these older records, Biström (1988b:218) 
also mentioned one from KA:Jimma. Régimbart's (1922) record of C. cribrosus from "Riviére Dobi" probably also refers to this species.

\section{Genus Yolina Guignot, 1936}

A small genus with nine species in Africa and Arabia that were revised by Biström (1983a). Only one species occurs in Ethiopia.

\section{Yolina insignis (Sharp)}

Bidessus insignis Sharp, 1882: $348+$ pl. 10:128.

This species occurs in Arabia and northeast Africa (Biström 1983a:61). The only Ethiopian record is from ER, "Gaharre à N. de Assab, Dancalie” (Capra 1952, as Yola elegantula).

\section{Genus Yola Gozis, 1886}

The 39 species recognized in this genus are confined to Africa and Asia, with one species found also in South Europe (Biström 1988c). More than 30 species occur in Africa, of which only four have been recorded from Ethiopia. Our treatment of this genus follows Biström's (1983a) revision.

\section{Yola tuberculata Régimbart}

Yola costipennis var, tuberculata Régimbart, 1895a: 68.

This species has a wide distribution in Africa south of the Sahara (Biström 1983a:17). The only Ethiopian record is from the Addis Ababa surroundings (Biström 1.c.).

\section{Yola darfurensis J. Balfour-Browne}

Yola darfurensis J. Balfour-Browne, 1947: 136.

Yola decorata Guignot, 1956b: 251.

This species is widely distributed in Central Africa and occurs also in the Yemen People's Republic (Biström 1983a:22). The only Ethiopian record is from GG:Arba-Minch (Biström 1983a:21).

\section{Yola frontalis Régimbart}

Yola frontalis Régimbart, 1906: 243.

Yola assimilis Omer-Cooper, 1931: 776.
Yola frontalis nyasaensis Omer-Cooper, 1959: 116. Yola assimilis rhodesiensis Omer-Cooper, 1959: 117. Yola assimilis rhodesiensis var. reticulata Omer-Cooper, 1959: 117.

Yola frontalis capensis Omer-Cooper, 1965a: 134. Yola frontalis ugandaensis Omer-Cooper, 1965a: 134.

This species has a wide distribution in the southern half of Africa (Biström 1983a:41). The subspecies Y.f. assimilis Omer-Cooper occurs at least in Ethiopia and Kenya, and maybe also in South Africa (Biström 1983a:42). It was first recorded from Ethiopia by Régimbart (1905, 1922) who listed it from ER and SH as $Y$. bicristata. Later, Omer-Cooper (1931) described it from Ethiopia as $Y$. assimilis, found at 1800 and $2400 \mathrm{~m}$ a.s.l. in SH. Some additional records were provided by Biström (1.c.).

Our three specimens were collected in the Dergo River, $14 \mathrm{~km} \mathrm{~S}$ of Sagure at $2550 \mathrm{~m}$ a.s.l. in AR.

\section{Yola enigmatica Omer-Cooper}

Yola enigmatica Omer-Cooper, 1954: 212.

This species occurs in a belt across the African continent from Mauritania to Ethiopia (Biström 1983a:51), as well as in Saudi Arabia (Brancucci 1984). The single Ethiopian record is from ER:Sitit Humera (Biström l.c.).

\section{Genus Hydrovatus Motschulsky, 1853}

This is a large genus with about 200 species of worldwide distribution in tropical and subtropical regions. More than 100 species occur in Africa. Our treatment of this genus follows Guignot (1959a), with later additions, mainly by Omer-Cooper. A modern revision of the genus is under preparation by Dr O.Biström, Helsinki. Besides the species listed below, Biström (in prep.) records also the following ones from Ethiopia: H. parvulus Régimbart, 1899, H. validicornis Régimbart, 1895 , and $H$. tydaeus $\mathbf{n}$. sp.

\section{Hydrovatus reticuliceps Régimbart}

Hydrovatus reticuliceps Régimbart, 1895a: 109.

This species is widely distributed in Central Africa, from Gabon to Tanzania (Guignot 
1959a:127) and Botswana (Bilardo \& Rocchi 1987:94). The Ethiopian records are from GO:Bahar Dar (in coll. SMNS), and KA:Jimma and $75 \mathrm{~km} \mathrm{SW}$ of Jimma (MRAC).

\section{Hydrovatus liberatus Guignot}

Hydrovarus liberatus Guignot, 1945: 9

This species was first described from Cameroon, and later reported from Zaire (Guignot 1959a:128). In Ethiopia it was collected at light in 1968 at GO:Bahar Dar (SMNS). According to Biström (in prep.) this species is identical with $H$. reticuliceps.

\section{Hydrovatus sordidus Sharp}

Hydrovatus sordidus Sharp, 1882: 327.

Hydrovatus humilis Shatp, 1882: 327.

This species has seemingly a wide distribution in Africa from Egypt and Mauritania to Zaire and maybe Mozambique (Omer-Cooper 1965a: 95). However, there is some confusion on the identity of this species, and the H. sordidus of Guignot (1959a:128) is another species (OmerCooper l.c.). It was first recorded from Ethiopia by Régimbart (1887) from Mt. Wann in SH. We have a single female from Metahara at $950 \mathrm{~m}$ a.s.l. in the same region (Fig. 2) that probably is this species. Wewalka $(1989: 145)$ treated $H$. humilis and $H$. sordidus as separate species and recorded both from Israel. According to Biström (in prep.) this species is identical with $H$. acuminatus Motschulsky, 1859, and widespread also in the Oriental Region.

\section{Hydrovatus badius Omer-Cooper}

Hydrovatus badius Omer-Cooper, 1931: 760, 761.

A chiefly East African species known from Sudan, Ethiopia, Uganda and Zaire (Guignot 1959a:130). It was recently recorded from Gabon (Bilardo \& Rocchi 1990). It was described from Ethiopia, where it had been collected at several localities between 1650 and $2300 \mathrm{~m}$ a.s.1. in AR and SH (Omer-Cooper 1931). Later, Guignot (1946:298) reported it from Namuruputh at $565 \mathrm{~m}$ a.s.l. in GG. Material from additional localities in SH, SI and GG were seen in MRAC.
Our only record of this species is from SI:Lake Awassa at $1600 \mathrm{~m}$ a.s.1. According to Biström (in prep.) Omer-Cooper's names is preoccupied by Clark, 1863 . The valid name of this species is instead $H$. deserticola Guignot, 1950, that belongs to an unsolved complex of at least three species.

\section{Hydrovatus absonus Guignot}

Hydrovatus absonus Guignot, 1948: 5, 6.

This species was described from Zaire (Guignot 1959a:133), and later reported also from Zambia (Pederzani 1988). The single Ethiopian record is from GO:Bahar Dar (Wewalka in litt.).

\section{Hydrovatus bredoi Gschwendtner}

Hydrovatus bredoi Gschwendtner, 1943: 421.

Hydrovatus differens Omer-Cooper, 1957: 39 + fig. 33 .

This species was described from Zaire, and Guignot (1959a:136) gave no additional localities. Omer-Cooper (1965a:94) established the synonymy given above and expanded the known range of $H$. bredoi to South Africa.

A long series was collected in Ethiopia at 1720 m a.s.l. near KA:Jimma (23-29.iv.1972, leg. de Rougemont, MRAC).

\section{Hydrovatus cuspidatus (Kunze)}

Hyphydrus cuspidatus Kunze, 1818: 68.

This species is widespread in the Palaearctic Region. It occurs in North Africa to Egypt and Ethiopia (Guignot 1959a:144). In Ethiopia it is confined to ER (Guignot 1.c.).

\section{Hydrovatus aristidis Leprieur}

Hydrovatus aristidis Leprieur, 1879: LXXXII.

This species was first described from Egypt, and Guignot (1959a:145) knew it also from the Ivory Coast, Mali and Mauritania. Later also recorded from Chad (Bruneau de Miré \& Legros 1963), and Gambia (LUM). In Ethiopia a single male was collected at IL:Gambela (x.1972 leg. de Rougemont, MRAC). 


\section{Hydrovatus procus Guignot}

Hydrovatus procus Guignot, 1942: 13.

According to Guignot (1959a:145, 146), this species was known only from the type locality in Uganda. The two Ethiopian records are from GO:Bahar Dar (in coll. SMNS), and KA:Jimma (MRAC). Biström (in prep.) has synonymized this species with $H$. spissicornis Régimbart (see below).

\section{Hydrovatus glomeratus Guignot}

Hydrovatus glomeratus Guignot, 1942: 13.

Hydrovatus consimilis Omer-Cooper, 1957: 30, 32 + fig. 27.

This species is known from Ethiopia, Botswana, Zimbabwe and South Africa (OmerCooper 1965a:99, Bilardo \& Rocchi 1987:96). It was first recorded from Ethiopia by Omer-Cooper (1931:760) as $H$. regimbarti from a stream W of Zaquala in SH. Later, Guignot $(1942,1946)$ described these specimens as the separate species $H$. glomeratus, and suggested that all specimens cited as $H$. regimbarti by Omer-Cooper (1.c.) belonged to the new species. Omer-Cooper (1965a:98) synonymized $H$. glomeratus with $H$. consimilis Omer-Cooper and suggested that also $H$. facetus Guignot could be the same species. According to Biström (in prep.), this species is identical with the next one.

\section{Hydrovatus simoni Régimbart}

Hydrovatus simoni Régimbart, 1894: 236.

This species is widely distributed in Africa south of the Sahara (Guignot 1959a:148, OmerCooper 1965a:97). The only Ethiopian record is from GO:Bahar Dar (Wewalka in litt.).

\section{Hydrovatus spissicornis Régimbart}

Hydrovatus spissicornis Régimbart, 1905: 207.

This species was described from the surroundings of Adi Caié in ER (Régimbart 1905). In the original description, Régimbart (1.c.) also mentioned another specimen from Gabon. If this species has such a wide distribution, it has probably been mixed up with some other species.
Hydrovatus regimbarti Zimmermann

Hydrovatus regimbarti Zimmermann, 1919: 127 (replacement name for Hydrovatus sharpi Régimbart, 1895, not Van den Branden, 1885).

Hydrovatus sharpi Régimbart, 1895a: 103, 104.

Hydrovatus navigator Guignot, 1942: 13.

This species has a wide distribution in Central Africa (Guignot 1959a:151). Omer-Cooper (1931:760) did not separate $H$. regimbarti and $H$. glomeratus, but according to Guignot (l.c.) her record of $H$. regimbarti from a water-hole $\mathrm{N}$ of Makki River at $1800 \mathrm{~m}$ a.s.l. in SH is valid. The male aedeagus was illustrated by Bilardo \& Pederzani (1978).

\section{Hydrovatus difformis Régimbart}

Hydrovatus difformis Régimbart, 1895a: 101.

Hydrovatus corniger Guignot, 1953a: 235.

This species is widely distributed in East and South Africa (Guignot 1959a:152, 153, OmerCooper 1965a:100). It was reported from four localities in Ethiopia at an altitude of 1700 to $2300 \mathrm{~m}$ a.s.1. in SH by Omer-Cooper (1931:760), and later collected at IL:Gambela (MRAC). The male genitalia were drawn by Omer-Cooper (1957:fig. 20).

We have a single male of this species from Lake Awassa at $1600 \mathrm{~m}$ a.s.l. in the SI province.

\section{Hydrovatus pescheti Omer-Cooper}

Hydrovatus pescheti Omer-Cooper, 1931: $761+$ pl. 8:7.

This species is known from Ethiopia, Uganda, Zaire and South Africa (Guignot 1959a:153, Omer-Cooper 1965a:99). It was described from Ethiopia (Omer-Cooper 1931), where it had been collected at 1500 and $2100 \mathrm{~m}$ a.s.l. in the AR and $\mathrm{SH}$ provinces. A series from KA:Jimma was examined in MRAC. The male genitalia were drawn by Omer-Cooper (1957:fig. 26).

\section{Hydrovatus villiersi Guignot}

Hydrovatus villiersi Guignot, 1955a: 860, 861.

Hydrovatus uncus Guignot, 1959a: 164.

This synonymy was suggested by Biström (in litt.). $H$. villiersi is distributed from Sudan to Malawi (Guignot 1959a:165), and Botswana (Bilardo \& Rocchi 1987:96). It was recorded 
from Ethiopia by Guignot (1946:306, 307, as $H$. obsoletus Peschet) from Namuruputh at Lake Turkana in GG, $565 \mathrm{~m}$ a.s.1. Also collected at light near Addis Ababa in SH (in coll. MZH).

\section{Hydrovatus nigricans Sharp}

Hydrovatus nigricans Sharp, 1882: 332.

Hydrovatus abotti Guignot, 1959a: 165.

This species is widely distributed in East and South Africa inclusive of Madagascar (Guignot 1959a:167, Omer-Cooper 1965a:103).

Our record from the SI prov. is seemingly the first one from Ethiopia. It was collected in Lake Awassa at $1600 \mathrm{~m}$ a.s.l.

\section{Hydrovatus compactus Sharp}

Hydrovatus compactus Sharp, 1882: 333.

This species was first described from Gabon and Guignot (1959a:168) recorded it also from Senegal, Zaire, Sudan and Egypt. The only Ethiopian specimens are from Addis Ababa in $\mathrm{SH}$, where they were collected at light in 1969 (in coll. MZH).

\section{Hydrovatus oblongipennis Régimbart}

Hydrovatus oblongipennis Régimbart, 1895a: 117, 118. Hydrovatus crassus Guignot, 1958: 5.

This species has frequently been misidentified. Omer-Cooper (1965a:201) recorded it from Senegal, Gabon, Dahomey, Zaire, Sudan and South Africa. The Ethiopian records are from Addis Ababa in SH, where they were collected at light in 1969 (in coll. MZH), and from IL:Pokwo (MRAC).

\section{Hydrovatus badeni Sharp}

Hydrovatus badeni Sharp, 1882: 333.

Hydrovatus subpunctatus Kolbe, 1883: 405.

Hydrovatus frater Régimbart, 1895a: 116.

Hydrovatus kivuamus Guignot, 1956b: 250.

This species is widely distributed in tropical Africa and on Madagascar (Omer-Cooper 1965a:103). Guignot (1959a:180) used the name $H$. badeni for another species, with the true $H$. badeni of Sharp described as $H$. frater. From
Ethiopia, H. badeni was recorded by OmerCooper (1931:762, as H. frater) from AR at 2100 $\mathrm{m}$ a.s.l. The male genitalia were illustrated by Omer-Cooper (1965a:102, fig. 16). According to Biström (in prep.), H. badeni and $H$. frater are two different species that both may occur in Ethiopia.

\section{Hydrovatus mundus Omer-Cooper}

Hydrovatus mundus Omer-Cooper, 1931: 762.

This species was first described from a single male from Suc Suci at Lake Zwai, $1650 \mathrm{~m}$ a.s.1, in SH in Ethiopia (Omer-Cooper 1931). Later, Balfour-Browne (1939a:482, 483) illustrated the male genitalia and gave some records from other East African countries as well as the Gold Coast. However, according to Guignot (1959a:189) the H. mundus of Balfour-Browne (1.c.) is H. uncus Guignot ( $=H$. villiersi Guignot). Consequently, the distribution of $H$. mundus is not very well known. With certainty it is known only from Ethiopia.

\section{Hydrovatus laticornis Régimbart}

Hydrovarus laricornis Régimbart, 1895a: 110, 111.

This species has seemingly a wide distribution in Africa south of the Sahara (Guignot 1959a:198, Omer-Cooper 1965a:96). It was recorded by Guignot (1946:299) from Ethiopia, GG, at 585$600 \mathrm{~m}$ a.s.l., and specimens from SH:Sodere and $\mathrm{KA}$ :Jimma were seen in MRAC.

We have this species from Lake Awassa in the SI prov., at $1600 \mathrm{~m}$ a.s.l. According to Biström (in prep.) the valid name of this species is $H$. cribratus Sharp, 1882.

\section{Hydrovatus longicornis Sharp}

Hydrovatus longicornis Sharp, 1882: 323.

This species is known from Ethiopia, Zaire (Guignot 1959a:201) and Gabon (Bilardo \& Rocchi 1990). It was first described from Egypt, but the proper labelling of the types has been questioned (Guignot 1.c.). Omer-Cooper (1931:760) reported it from several localities in the AR and $\mathrm{SH}$ provinces in Ethiopia, ranging from 1500 to $2300 \mathrm{~m}$ a.s.1. 
Genus Herophydrus Sharp, 1882

The 46 species of this genus are largely confined to Africa (Franciscolo 1979:318). A few species occur in the southern part of the Palaearctic Region, and H. musicus (Klug) is also found in the Oriental Region as far east as Burma. The African species were treated by Guignot (1959b). The genus needs to be revised.

\section{Herophydrus muticus (Sharp)}

Coelambus muticus Sharp, 1882: $398+$ pl. 12:146.

This species is endemic to Ethiopia. Sharp (1882) described it from "Goumdet, Agaos and Lake Tzana". Régimbart (1887) reported it from SH:Fallé and Let-Marefià, and later also from ER (Régimbart 1905) and other regions (Régimbart 1922). Later, Omer-Cooper (1931:779) listed it from several localities from 1650 to $2700 \mathrm{~m}$ a.s.l. A record from SH:Bargà was presented by Rocchi (1975a). Also known from TI:Adigrat (in coll. MZH).

This is a very common species in the highlands, and we have almost 800 specimens from 13 sites in AR, ranging in altitude from 2350 to $3100 \mathrm{~m}$ a.s.1. We have it also from single sites in BA and SH. It occurs in both lentic and lotic waters (Figs. 5, 6).

\section{Herophydrus quadrilineatus Régimbart}

Herophydrus quadrilineatus Régimbart, 1895a: 38, $39+$ fig. 6.

This species is endemic to Ethiopia. It was first described from SH:Acachi (Régimbart 1895a). Later, Omer-Cooper (1931:779) reported it from additional sites between 2400 and 2700 $m$ a.s.1. in SH. A record from SH:Bargà was presented by Rocchi (1975a).

We have 37 specimens of this species from $3100 \mathrm{~m}$ a.s.l. at the Mt. Galema in AR. It was here found in a small shallow lake (Fig. 6) and in the outlet of the lake.

\section{Herophydrus guineensis (Aubé)}

Hyphydrus guineensis Aubé, 1838: 455. Hyphydrus turgidus Erichson, 1843: 220. Hydroporus hyphydroides Perris, 1864: 277. Herophydrus umbrosus Zimmermann, 1926: 29.
This species is widely distributed in Africa except the southernmost part (Guignot 1959b: 353). It is also found on the islands of Corsica, Sardinia and Sicilia, as well as in Arabia (Franciscolo 1979:318, 319). It was reported from Goro-Gomotou in Ethiopia by Régimbart (1922), and Omer-Cooper (1931:780) listed several records from between 1500 and $2300 \mathrm{~m}$ a.s.l. in $\mathrm{SH}$, where it is also known from Coca $(\mathrm{MZH})$. Additional records are from GO:Bahar Dar (in coll. SMNS) and SI:Noikein (in coll. MRAC).

\section{Herophydrus sobrinus Omer-Cooper}

Herophydrus inquinatus var. sobrinus Omer-Cooper, 1931: $779+$ pl. 9:3.

This species was first described from the surroundings of the Lake Zwai in Ethiopia at $1650 \mathrm{~m}$ a.s.l. (Omer-Cooper 1931). Later, Guignot (1959b:357) listed many records from Zaire and also assigned some specimens from Hora Horeso at $2100 \mathrm{~m}$ a.s.l. in Ethiopia to this species. OmerCooper (1931:778) had identified the series from this locality as $H$. inquinatus (Boheman). Both $H$. sobrinus and $H$. pallidus Omer-Cooper may only represent forms of $H$. inquinatus, as suggested by Omer-Cooper (1965a). This complex needs to be revised.

\section{Herophydrus pallidus Omer-Cooper}

Herophydrus inquinatus var. pallidus Omer-Cooper, 1931: $778+$ pl. 9:1.

Herophydrus colasi Guignot, 1935: 38-40.

Herophydrus expressus Gschwendtner, 1938a: 8, 9 + fig. 2 .

This species was first described from Hora Bishoftu and Hora Harsadi at $2300 \mathrm{~m}$ a.s.l. in SH in Ethiopia as a pale form of $H$. inquinatus (OmerCooper 1931). Guignot (1959b:362) synonymized $H$. pallidus with his $H$. colasi, described from Kenya, and also with $H$. expressus Gschwendtner, described from Zaire. As H. pallidus is the oldest name it takes priority over $H$. colasi.

Omer-Cooper (1931:778) reported on long series of $H$. inquinatus from the same two sites as $H$. pallidus were collected at. According to Gschwendtner (1938a:8) these specimens were not $H$. inquinatus, but instead the new species $H$. cooperi. However, Guignot (1959b:362-364) considered this material as mixed and considered 
the type identical with $H$. inquinatus, and some of the other specimens identical with $H$, pallidus.

We have single females from $2200 \mathrm{~m}$ a.s.l. in $\mathrm{SH}$ and $1600 \mathrm{~m}$ a.s.l. in SI that seemingly belong to this species.

\section{Herophydrus inquinatus (Boheman)}

Hydroporus inquinatus Boheman, 1848: 254.

Herophydrus ignoratus Gschwendtner, 1933: 87-89.

Herophydrus kalaharii Gschwendtner, 1935: 20.

Herophydrus cooperi Gschwendtner, 1938a: 8 + fig. 2 .

This is an East African species common from Ethiopia to Malawi and becoming rarer in the southern parts of its range (Guignot 1959b:364, Omer-Cooper 1965a:144). It was reported from four sites in Ethiopia by Omer-Cooper (1931:778), but as seemingly other species also were included only the record from Hora Horeso at $2100 \mathrm{~m}$ a.s.l. has been verified (Guignot 1959b:363).

Harrison \& Hynes (1988) recorded this species from $3000 \mathrm{~m}$ a.s.l. near Addis Ababa. Probably, they used this name in its wider sense, i.e. inclusive of the two previous species.

\section{Herophydrus erythraeus Régimbart}

Herophydrus erythraeus Régimbart, 1904: 2.

This species is known from Ethiopia, Zaire and Angola (Guignot 1959b:367). It was described from ER (Régimbart 1904), with additional records presented later (Régimbart 1905), and also collected at Asmara (in coll. MZH). Omer-Cooper (1931:778) reported it from three sites at 1800 and $2100 \mathrm{~m}$ a.s.l. in $\mathrm{AR}$ and SH.

\section{[Herophydrus nodieri (Régimbart)}

Coelambus nodieri Régimbart, 1895a: 37.

This species is known from Sudan, Senegal, Uganda and Zaire, and Guignot (1959b:370) also mentioned it from Ethiopia with a question-mark. This record needs verification.]

\section{Genus Heterhydrus Fairmaire, 1869}

This is a small genus with five species confined to Africa and Madagascar (Wewalka 1980). Only one species has been found in Ethiopia.

\section{Heterhydrus sudanensis Zimmermann}

Heterhydrus sudanensis Zimmermann, 1927: 33, 34 + fig. 1.

This species was described from Sudan (Zimmermann 1927:34), and later reported also from Zaire (Guignot 1959c:135). A single male from Ethiopia is from IL:Gambela, $30 \mathrm{~km} \mathrm{~W}$ Abobo (20.vii.1984 leg. Rybalov SMNS).

Genus Hyphydrus Illiger, 1802

This is a large genus with some 100 species in Europe, Asia, Africa and Australia. Of the numerous African species only 12 occur in Ethiopia, and our treatment of the genus follows Biström's (1982) revision.

\section{Hyphydrus parvicollis Sharp}

Hyphydrus parvicollis Sharp, 1882: 375.

This species is widely distributed in tropical Africa south to Botswana (Biström 1982:16). The known Ethiopian records are from $\mathrm{SH}$ and $\mathrm{IL}$ (Biström 1.c.).

\section{Hyphydrus grandis Laporte}

Hyphydrus grandis Laporte, 1835: 107.

Hyphydrus major Sharp, 1882: 375.

This species has a wide distribution in Africa from Egypt to Zaire (Biström 1982:26, 27). Records from ER and IL:Gambela were provided by Biström (l.c.).

\section{Hyphydrus fuscus Omer-Cooper}

Hyphydrus fuscus Omer-Cooper, 1931: $764+$ pl. 8:8.

This species is endemic to Ethiopia. It was first described from Addis Ababa at $2400 \mathrm{~m}$ a.s.l. (Omer-Cooper 1931). A second record is from GG:Chencha at $2700 \mathrm{~m}$ a.s.1. (Biström 1982:34).

\section{Hyphydrus silfverbergi Biström}

Hyphydrus silfverbergi Biström, 1982: 53 + fig. 45.

This species is endemic to Ethiopia, where it is known from the type locality at Shebe in KA (Biström 1982), and from ER (Biström 1984b:52). 


\section{Hyphydrus nigrovittatus Régimbart}

Hyphydrus nigrovittatus Régimbart, 1906: 240.

Biström (1982:54, 1983b:118) examined material of this species from Zaire, Kenya and Tanzania. The only record from Ethiopia is from GD:Debra Tabor (Capra 1952).

\section{Hyphydrus cycloides Régimbart}

Hyphydrus cycloides Régimbart, 1889: 56.

Hyphydrus circularis Régimbart, 1895a: 53.

Hyphydrus pelates Guignot, 1953b: 1.

Hyphydrus lamottei Legros, 1958: 212.

This species has a wide distribution in Africa south of the Sahara inclusive of Madagascar. The only record from Ethiopia is from $75 \mathrm{~km}$ SW of Jimma at $1450 \mathrm{~m}$ a.s.l. in KA (Biström 1982:67).

\section{Hyphydrus signatus Sharp}

Hyphydrus signatus Sharp, 1882: 379.

Hyphydrus grossus Sharp, 1882: 378.

Hyphydrus aethiopicus J. Balfour-Browne, 1944: 345 (replacement name for Hyphydrus grossus Sharp, 1882, not Müller, 1776).

Hyphydrus grossus ab. ablutus Guignot, 1936: 18, 19.

Hyphydrus aethiopicus ab. bechynei Guignot, 1950: 270.

This species is widely distributed in Africa south of the Sahara (Biström 1982:79, 80). It was first reported from Ethiopia by Régimbart (1895b) from AR, and later Omer-Cooper (1931:763, as H. grossus) listed several localities at 1650 to $2400 \mathrm{~m}$ a.s.I. in AR and SH. Additional records from many provinces were listed by Guignot (1959b) and Biström (l.c.).

We have 42 individuals of this species from nine sites in $\mathrm{AR}, \mathrm{BA}$ and $\mathrm{SH}$, ranging in altitude from 1500 to $2600 \mathrm{~m}$ a.s.l. Almost all specimens were collected in small stagnant waters (Figs. 3-5).

\section{Hyphydrus pictus Klug}

Hyphydrus pictus Klug, 1834: t. 33, f. 9.

Hyphydrus lugubris de Borre, 1870: X.

This species occurs in Iran, Arabia and NE Africa to Somalia (Biström 1982:82). It was reported from ER by Régimbart (1905), and also from WO:Alamata by Biström (1.c.).

\section{Hyphydrus puncticollis Sharp}

Hyphydrus puncticollis Sharp, 1882: 379.

This species was first described from Ethiopia (Sharp 1882), which is the main area of distribution. Single records are otherwise known from Angola and maybe Zaire (Biström 1982:84). Régimbart $(1887,1905,1922)$ reported this species from several sites in ER and SH. OmerCooper (1931:763) listed many records from 2100 to $2700 \mathrm{~m}$ a.s.l. in AR and SH. Some additional records were presented by Biström (l.c.).

We have in our material 557 specimens of $H$. puncticollis from 18 localities in AR, BA and $\mathrm{SH}$, ranging in altitude from 2350 to $3100 \mathrm{~m}$ a.s.l. This is one of the commonest species in the AR highlands, where it occurs in all kinds of running and stagnant waters (Figs. 4-6), often in very high numbers.

\section{Hyphydrus abyssinicus Peschet}

Hyphydrus abyssinicus Peschet, 1916: 202.

This species is endemic to Ethiopia. It is so far known only from Harrar, the type locality (Biström 1982:84).

\section{Hyphydrus maculatus Babington}

Hyphydrus maculatus Babington, 1841: 12.

Hyphydrus crassus Wollaston, 1867: 33.

Hyphydrus africanus Sharp, 1882: 376.

Hyphydrus africanus var, borkuanus Bruneau de Miré \& Legros, 1963: 843 + fig. 1 .

This species is widespread in North and Central Africa, inclusive of the Canary Islands and the Cap Verde (Biström 1982:86). The only record from Ethiopia is from ER:Setit Humera (Biström l.c.).

\section{Hyphydrus impressus Klug}

Hyphydrus impressus Klug, 1833: 48.

Hyphydrus coquerelii Fairmaire, 1869: 186.

Hyphydrus flavicollis Régimbart, 1895a: 58 + fig. 15 .

This species is widespread in Africa except for the northernmost part, and also occurring on Madagascar (Biström 1982:107-109). It was first recorded from Ethiopia by Omer-Cooper (1931: 
764), who listed it from two sites at 1800 and $2300 \mathrm{~m}$ a.s.1. in SH. Biström (1.c.) presented some records down to $1000 \mathrm{~m}$ a.s.l. in $\mathrm{SH}$, and from $480 \mathrm{~m}$ a.s.l. near Lake Turkana in GG.

We have a single specimen from Dehra, $40 \mathrm{~km}$ $\mathrm{N}$ of Asella at 1800 a.s.1. in AR, collected in a manmade pond without vegetation on 25.ix.1988. Four additional specimens were collected in ponds at 950 and $1500 \mathrm{~m}$ a.s.l. in SH (Fig. 2).

\section{Genus Peschetius Guignot, 1942}

A small genus with six rare species in tropical Africa and two in India. The African species were treated by Omer-Cooper (1970a). Only one species has been found in Ethiopia.

\section{Peschetius carinipennis (Régimbart)}

Hydroporus carinipennis Régimbart, 1895a: 15, 16 + fig. I.

This species was first described from Zaire and subsequent records include Kenya, Mocambique, Zimbabwe and South Africa (OmerCooper 1970a). We have seen a single male from IL: Gambela in Ethiopia (21-23.v.1972 leg. Clarke MRAC).

\section{Genus Nebrioporus Régimbart, 1906}

Nilsson \& Angus (1992) recently synonymized Potamonectes Zimmermann with Nebrioporus in a reclassification of the Deronectesgroup of genera. Most of the about 60 species are Palaearctic, and a few species are known from the Nearctic, Oriental, and Afrotropical Regions. The latter includes three species in South Africa, and five or six species in East Africa. Besides $N$. kilimandjarensis (Régimbart), the East African species belong to the abyssinicus-group revised by Nilsson (1992a). Four species are known from Ethiopia.

\section{Nebrioporus abyssinicus (Sharp)}

Deronectes abyssinicus Sharp, 1882: 431 + pl. 12:153. Hydroporus abyssinicus var. atratus Régimbart, 1908: 2. Hydroporus abyssinicus var. flavidus Régimbart, 1908: 2, 3.

This species is known from Ethiopia, Kenya and Tanzania (Nilsson 1992a). It was first de- scribed from Ethiopia (Sharp 1882). Régimbart (1887) recorded it from SH:Fallé, and later (Régimbart 1905) also from ER and IL (“Ourbou”) (Régimbart 1922). It was recorded from between 2300 and $2400 \mathrm{~m}$ a.s.1. in SH by Omer-Cooper $(1931: 780,781)$. The records given by Harrison \& Hynes (1988) refer to other species. Known also from WO:Tossa Ancho near Desse (leg. de Rougemont 1974, MRAC).

In total, we have 1080 specimens of $N$. abyssinicus from 13 sites in $\mathrm{AR}$ and one in $\mathrm{SH}$, representing an altitudinal range from 2350 to $3100 \mathrm{~m}$ a.s.l. Most frequently it was collected in various running waters, but also found in ponds with no or little vegetation (Figs. 5, 6).

\section{Nebrioporus cooperi (Omer-Cooper)}

Deronectes cooperi Omer-Cooper, 1931: 781, $782+$ pl. $9: 6$.

This species is endemic to Ethiopia (Nilsson 1992a). It was described from Ethiopia at 2400 to $2500 \mathrm{~m}$ a.s.1. in SH (Omer-Cooper 1931). Guignot (1959e) presented a record from ER. It is also known from the Simien Mts. in GD (Wewalka in litt.), and from AR and BA (Nilsson 1992a).

We have 45 specimens of $N$. cooperi from three different localities in AR, ranging in altitude from 2350 to $3100 \mathrm{~m}$ a.s.l. Most specimens were collected in a small stream at Bilalo, but it was also found in the outlet of a small lake at Mt. Galamo (Fig. 6).

\section{Nebrioporus scotti (Omer-Cooper)}

Deronectes scotti Omer-Cooper, 1931: 781 + pl. 9:6.

This species is endemic to Ethiopia. It was first described from Mulu, above Muger Valley, at $2400 \mathrm{~m}$ a.s.l. in SH (Omer-Cooper 1931). It is also known from Let. Marefia in the same province, and from GD:Tucul Dangia, F. Maana (Nilsson 1992a).

\section{Nebrioporus tellinii (Régimbart)}

Hydroporus tellinii Régimbart, 1904: 1.

This species is endemic to Ethiopia. It was first described from ER (Régimbart 1904), with 
additional records, one from $2200 \mathrm{~m}$ a.s.1., presented later (Régimbart 1905). A redescription of this species was given by Rocchi (1975b). It has also been found in the Simien Mts. in GD (Wewalka in litt.). Additional records from $\mathrm{SH}$ were listed by Nilsson (1992a).

We have 96 specimens of $N$. tellinii from five localities at 2500 to $3100 \mathrm{~m}$ a.s.l. in AR. It was collected in various running waters (Fig. 5). At Mts. Titchio it was collected between 3200 and $3500 \mathrm{~m}$ a.s.l. (leg. Clarke 1972, MRAC).

\section{Subfamily Colymbetinae Erichson, 1837}

\section{Genus Copelatus Erichson, 1832}

This is a large genus with about 400 described species. The distribution is almost worldwide with centers of diversity in South America, Africa and Indo-Australia. More than 100 species are known from Africa, with 17 of them recorded from Ethiopia. The African species were reviewed by Guignot (1961), whose treatment of the genus is followed here. A revision of this genus is badly needed.

\section{Copelatus erichsoni Guérin-Méneville}

Copelatus erichsoni Guérin-Méneville, 1849: 270.

This species belongs to a complex of forms of unknown status (Balfour-Browne 1939b:83, Omer-Cooper 1965a:171). Consequently, we have chosen not to give any synonyms, but these were listed by Omer-Cooper (1965a:170). C. erichsoni was described from Ethiopia (GuérinMéneville 1849), and in its wider sense this species is widely distributed in Africa south of the Sahara (Omer-Cooper 1965a:171, 172). Régimbart (1895b, 1905) recorded it from AR and ER, and Omer-Cooper (1931:714, 785) listed it from $\mathrm{AR}$ and $\mathrm{SH}$ at altitudes from 1800 to $2500 \mathrm{~m}$ a.s.l. It has also been found at GO:Bahar Dar (in coll. SMNS \& MRAC) and in HA, IL and KA (MRAC). Two specimens from HA had the very shallow elytral striae and more laterally restricted pronotal striolation characteristic for the form polystrigus Sharp.

We have only 12 specimens from two sites in $\mathrm{AR}$ and one in SH, all at $2350 \mathrm{~m}$ a.s.l. It was only collected in more or less temporary, small stagnant waters (Fig. 4).

\section{Copelatus atrosulcatus Régimbart}

Copelatus atrosulcatus Régimbart, 1906: 251.

This is an East African species that was described partly from AR:Ganale Gudda in Ethiopia (Régimbart 1906). Régimbart (1895a, b) first included these specimens in his Copelatus owas, a species confined to Madagascar (Guignot 1961: 679). Omer-Cooper (1931:785) listed it from several localities in AR and SH, from 1800 to $2500 \mathrm{~m}$ a.s.l., both from lotic and lentic waters. It was later taken at light at $\mathrm{KA}$ :Jimma and Agare (in coll. MZH). Specimens were also seen from IL, GG and SI (MRAC).

We have 20 specimens of $C$. atrosulcatus from four localities in AR and two in SH, ranging in altitude from 1500 to $2500 \mathrm{~m}$ a.s.l. Most specimens were collected in ponds (Fig. 4).

\section{Copelatus hararensis Guignot}

Copelatus hararensis Guignot, 1952a: 22, 23.

Copelatus harrarensis Guignot, 1961: 682 (unjustified emendation).

This species was described from Harrar in Ethiopia (Guignot 1952a). It may be endemic to Ethiopia, but the Arabian record of C.atrosulcatus presented by Balfour-Browne (1939b:83) could represent $C$. hararensis (Guignot 1961:680). The record of $C$. atrosulcatus from Harrar given by Régimbart (1922) most probably refers to $C$. hararensis.

\section{Copelatus edax Guignot}

Copelatus edax Guignot, 1955b: 5.

This species was described from Zaire, and Omer-Cooper (1965a:172) recorded it also from Tanzania and South Africa. Bilardo \& Pederzani (1972) noted that $C$. edax may be a form of $C$. atrosulcatus and included Sudan, Kenya, Uganda and Ethiopia in the distribution.

\section{Copelatus bottegoi Régimbart}

Copelatus bottegoi Régimbart, 1895a: 174.

This species was described from AR:Ganale Goudda in Ethiopia (Régimbart 1895a, b). 
Appearingly, this is the only record from Ethiopia. C. bottegoi is now known also from Somalia, Zaire, Togo (Guignot 1961:683, 684), and Ivory Coast (Bilardo \& Pederzani 1979:122).

\section{Copelatus andreinii Régimbart}

Copelatus andreinii Régimbart, 1905: 208.

This species was described from ER:Adi-Ugri (Régimbart 1905). Subsequent Ethiopian records are from GO:Bahar Dar, GG:Jinka and several sites near Jimma in KA (MRAC). C. andreinii is also known from the Ivory Coast (Bilardo \& Pederzani 1979:124).

\section{Copelatus aethiopicus Régimbart}

Copelatus aethiopicus Régimbart, 1906: 250, 251.

Copelatus congo Gschwendtner, 1938a: 11 + fig. 3 .

This is an East African species. It was described from Anato, Gindeberat at the Blue Nile (Régimbart 1906), and later (Régimbart 1922) reported from Kounhi. Omer-Cooper (1931:783) listed $C$. aethiopicus from three localities at 2400 to $2500 \mathrm{~m}$ a.s.l. in $\mathrm{SH}$. Also known from KA:Jimma (in coll. MZH \& MRAC), SI:80/88 $\mathrm{km} \mathrm{S}$ of Dilla (leg. Clarke 1975, MRAC), and IL:15 km NW of Ehora (leg. de Rougemont 1973, MRAC).

We have a single female from a seasonal forest pond near Assella at $2350 \mathrm{~m}$ a.s.l. in AR.

\section{Copelatus pulchellus (Klug)}

Agabus pulchellus Klug, 1834: tab. 33, fig. 7.

Colymbetes marginipennis Laporte, 1835: 102.

Copelatus basalis Boheman, 1848: 244.

Copelatus obtusus Boheman, 1848: 242.

Copelatus discoideus Sharp, 1882: 582.

Copelatus aficanus Sharp, 1882: 583.

This species was described from Sinai. It belongs to a difficult complex revised by BalfourBrowne (1950), and the penis was also illustrated by Bilardo \& Pederzani (1972). The distribution includes most of tropical Africa (Omer-Cooper 1965a:168). From Ethiopia, single males were seen from ER:Setit Humera (1973 leg. Crowe MRAC), SH:Awash Natn. Pk. (1971 leg. Clarke MRAC), and IL:Gambela (leg. Rybalov, coll. Hendrich).

\section{Copelatus scytalotus Guignot}

Copelatus scytalotus Guignot, 1956c: 89.

This species was described from Mali, and recorded also from Sudan (Wewalka, in litt.). In Ethiopia, a single male was collected at IL:Gambela, $30 \mathrm{~km} \mathrm{~W}$ of Abobo (20.vii.1984 leg. Rybalov SMNS).

\section{Copelatus latus J. Balfour-Browne}

Copelatus latus J. Balfour-Browne, 1950: 368 + figs. 7, 8.

This species was previously known from Zimbabwe and Zaire (Guignot 1961:717). From Ethiopia we have seen a single female from IL:Gambela (leg. de Rougemont 1972, MRAC; det. A.Bilardo).

\section{Copelatus waltoni J. Balfour-Browne}

Copelatus waltoni J. Balfour-Browne, 1950: 373 + figs. $13,14$.

This species was previously known from Sierra-Leone and Zaire (Guignot 1961:719). The Ethiopian records are from GO:Bahar Dar (in coll. SMNS \& MRAC) and KA:75 km SW of Jimma (leg. Clarke 1972, MRAC).

\section{Copelatus fontanus J.Balfour-Browne}

Copelatus fontanus J.Balfour-Browne, 1950: 373, 374, figs. $15,16$.

This species was first described from a single male collected in Sudan. Guignot (1961:720) knew it also from Zaire. In Ethiopia, it was collected at light near IL:Gambela (27.viii.1972, 107 , leg. Clarke, MRAC).

\section{[Copelatus striatulus Aubé}

Copelatus striatulus Aubé, 1838: 385.

This species was described from Senegal. It has later been recorded from many other countries, but Omer-Cooper (1965a:167) considered these records very uncertain. Guignot (1961:721) reported C. striatulus from Ethiopia with some doubt. According to Omer-Cooper (1965a:167), the striatulus of Guignot (l.c.) is at least partly mixed up with $C$. pulchellus Klug. The occurrence of $C$. striatulus in Ethiopia should be verified before accepted.] 


\section{Copelatus ragazzii Régimbart}

Copelatus ragazzii Régimbart, 1887: 4:637.

Copelatus asemus Omer-Cooper, 1931: 783, 784 + fig. $2+$ pl. 1:6.

This species is endemic to Ethiopia. It was described from SH:Fallé (Régimbart 1887), and later reported also from AR:Gamale Gudda (Régimbart 1895a:161, 1895b). Omer-Cooper (1931:782-784, as C. ragazzii and C. asemus) gave records from 2100 to $2700 \mathrm{~m}$ a.s.l. in $\mathrm{AR}$ and SH.

We have 385 specimens of $C$. ragazzii from 12 sites in AR and two sites in SH, ranging in altitude from 2350 to $3100 \mathrm{~m}$ a.s.l. This was the only common species of Copelatus in the AR highlands, and it was collected both in ponds and streams (Figs. 4-6).

\section{Copelatus decemsulcatus Régimbart}

Copelatus decemsulcatus Régimbart, 1895a: 161.

This species was described from Ghana and later reported also from the Ivory Coast and $\mathrm{Za}$ ire (Guignot 1961:732). The penis is illustrated by Franciscolo \& Sanfilippo (1986). We have seen a single female from Ethiopia IL:Gambela (leg. de Rougemont 1972 MRAC).

\section{Copelatus parallelipipedus Régimbart}

Copelatus parallelipipedus Régimbart, 1895a: 159, fig. 67. Copelatus patrizii Peschet, 1922: 376.

This species is widespread in West and East Africa south to Mocambique (Guignot 1961:735). The only Ethiopian record is from KA:Jimma at $1700 \mathrm{~m}$ a.s.l. (1971-72 leg. Clarke MRAC).

\section{Copelatus pumilus Régimbart}

Copelatus pumilus Régimbart, 1895a: 158, 159.

This species was described from Ethiopia, and has later been recorded also from Zaire (Guignot 1961:736). Omer-Cooper (1931:782) recorded a single female from Mulu at $2400 \mathrm{~m}$ a.s.l. in SH. The male is not known.

\section{Copelatus parisii Guignot}

Copelatus parisii Guignot, 1959e: 356.

This species is endemic to Ethiopia. It is only known from Adamò and Pozzi Giarabà in ER, where it was collected in 1923 (Guignot 1959e).
Genus Aglymbus Sharp, 1882

This is a small genus with about 25 species in South America, Africa, and on Madagascar (Guéorguiev 1968, Franciscolo 1979:242). Nine species are confined to Madagascar and the Comores (Wewalka 1982), and the three African species have all been found in Ethiopia (Nilsson 1991b).

\section{Aglymbus gestroi Sharp}

Aglymbus gestroi Sharp, 1882: 597.

This species was described from a single female from Seiotel, Bogos, in Eritrea (Sharp 1882). Wewalka (1974) described the male and gave records of $A$. gestroi from Egypt and Israel. Later also reported from Saudi Arabia (Brancucci 1980).

\section{Aglymbus brevicornis Sharp}

Aglymbus brevicornis Sharp, 1882: 597, 598.

A rare species, previously known only from the female holotype that was collected in Ethiopia (Guignot 1961:747). We have seen a second female from a tributary to the Abo River at 2500 $\mathrm{m}$ a.s.l. in SH (in coll. MZH), and a third one from GD:Simien Mts. Geech (8-9.ix.1974 leg. Bosmans MRAC). The female from GD is relatively broader and lacks the elytral striolae external to the first stria present in the $\mathrm{SH}$ female. The study of more material is needed to establish the status of these forms.

\section{Aglymbus multistriatus Nilsson}

Aglymbus multistriatus Nilsson, 1991b: 76-78.

This species is endemic to Ethiopia. It is only known from KA. The type locality is Gembi near Agaro where it was taken at light (Nilsson 1991b). Four additional females were collected near Jimma (vii-viii.1971 leg. de Rougemont MRAC).

\section{Genus Agabus Leach, 1817}

This is a large genus with about 200 species, mainly in the Holarctic Region. The thirteen Afrotropical species were recently revised by Nilsson (1992b). In this region, the genus is confined to the mountains of Ethiopia and East Africa. One species has a wider distribution that 
includes also South Africa. So far, ten species are known from Ethiopia.

\section{Agabus discicollis Ancey}

Agabus discicollis Ancey, 1883: 70.

This species was described from Ethiopia where it was collected by Raffray (1885) in cold, rapid streams between 3500 and $4000 \mathrm{~m}$ a.s.l. on Mt. Abuna Yosef in WO. A. discicollis is endemic to Ethiopia and the single additional record known to us is from GD:Gimabar stream $5 \mathrm{~km} \mathrm{~S}$ of Geech at $3170 \mathrm{~m}$ a.s.l. (22.x.1973 leg. Clarke MRAC; Wewalka in litt.). We have followed Derksen \& Scheiding (1963) in dating Ancey's description of this species to 1883 .

\section{Agabus ambulator Régimbart}

Agabus ambulator Régimbart, 1895a: 152.

This species was described from Ethiopia. Wewalka \& Nilsson (1990) presented a redescription with more recent records from GD, $\mathrm{SH}$, and SI. Also known from GO: Mt. Choke and AR: Mts. Badda and Mts. Titchio (leg. Clarke 1972, in coll. MRAC). The type locality is most probably located on the Mt. Abuna Yosef in WO, between 3500 and $4000 \mathrm{~m}$ a.s.l. (Raffray 1885). It occurs in running waters at altitudes above $2900 \mathrm{~m}$ a.s.l.

\section{Agabus loeffleri Wewalka \& Nilsson}

Agabus loeffleri Wewalka \& Nilsson, 1990: 152.

This species was described from the Bale Mts. and the Mt. Galama in AR, where it had been found in rivers and small lakes (Wewalka \& Nilsson 1990). An additional record is from AR: Mts. Titchio, $16 \mathrm{~km}$ E of Dighellu (leg. Clarke 1972, MRAC). The four known localities are situated between 3200 and $4000 \mathrm{~m}$ a.s.l., and the species is restricted to the eastern side of the Rift Valley in South Ethiopia.

\section{Agabus raffrayi Sharp}

Agabus raffrayi Sharp, 1882: 501, 502.

Agabus limbicollis Régimbart, 1905: 224, 225.

This species was first described from Ethiopia. It is endemic to Ethiopia, and previous records from East and South Africa are erroneous (Nilsson 1992b). Omer-Cooper (1931:785) recorded $A$. raffrayi from five sites in $\mathrm{SH}$ and one in $\mathrm{AR}$ ranging in altitude from 2100 to $2700 \mathrm{~m}$ a.s.l. Rocchi (1975a) provided a record from SH:Bargá, and Jackson (1956) reported on specimens from $3000 \mathrm{~m}$ a.s.l. at Mt. Damota in SI. It is also known from about 3000 m a.s.l. in GD: Simien Mts. (leg. Scott, 1952 BMNH, leg. de Rougemont 1973 MRAC), GO: Mt. Choke (leg. Clarke 1972 MRAC) and a few localities in $\mathrm{AR}$ and $\mathrm{BA}$ (MRAC).

We have 399 specimens of $A$. raffrayi from 11 localities in AR, two in BA, and one in $\mathrm{SH}$, ranging in altitude from 2350 to $3100 \mathrm{~m}$ a.s.l. (Nilsson \& Persson 1990). The species was frequently found both in lentic and lotic waters, usually more or less temporary (Fig. 5).

\section{Agabus pallidus Omer-Cooper}

Agabus pallidus Omer-Cooper, 1931: 786, 787, fig. 3a, pl. $9: 7$.

This species was first described from Ethiopia between Addis Ababa and Addis Alem at 2250 $\mathrm{m}$ a.s.l. in Shoa (Omer-Cooper 1931). The status of $A$. pallidus has been under dispute, and we have earlier presented data in support of its recognition as a valid species (Nilsson \& Persson 1990), and not a form of A. raffrayi. Previous records of $A$. pallidus from outside Ethiopia refer to other species (Nilsson 1992b). It was recorded at $3000 \mathrm{~m}$ a.s.l. at Mt. Gughé in GG by Jackson (1956), and collected by Löffler at $4000 \mathrm{~m}$ a.s.l. in the Bale Mts. (coll. Wewalka). Many specimens were seen from sites between 3040 and $3930 \mathrm{~m}$ a.s.l. in AR and BA, and a single female is from GD:Simien Mts. Geech area at $3500 \mathrm{~m}$ (MRAC).

We have 332 specimens of $A$. pallidus from nine localities in $A R$ and one in $B A$, ranging in altitude from 2350 to $3100 \mathrm{~m}$ a.s.1. It was collected in small lakes, ponds and streams (Figs. 5, 6), usually more or less temporary.

\section{Agabus ragazzii Régimbart}

Agabus ragazzii Régimbart, 1887: 638.

Agabus ferrugatus Régimbart, 1905: 225.

This species was first described from SH: Fallé, where it was collected in 1885 (Régimbart 1887), and later from AR:Auadi (Régimbart 
1905). Omer-Cooper (1931:787) provided records from three additional localities in $\mathrm{SH}$, from 2250 to $2550 \mathrm{~m}$ a.s.1., and the species is endemic to Ethiopia. Additional records from $\mathrm{SH}$ are from the Abo River at $2450 \mathrm{~m}$ a.s.l. (Harrison \& Hynes 1988, station 2C), and from Shashamaanni (leg. Linnavuori 1963, MZH). Known also from $\mathrm{KA}$ :Shebe (MZH).

We have 26 specimens from a stream near SH:Burraju, $15 \mathrm{~km}$ W of Addis Ababa at $2600 \mathrm{~m}$ a.s.l. The stream was $2-3 \mathrm{~m}$ wide with vegetated margins. All specimens were collected on 24.x.1988 and in early March 1989 the stream carried much less water and no specimens of $A$. ragazzii were found.

\section{Agabus perssoni Nilsson}

Agabus perssoni Nilsson, 1992b: 172.

This species was recently described from AR: Asella. Bilardo \& Pederzani (1979; as A. ferrugatus) described the male from BA at $3040 \mathrm{~m}$ a.s.l. Known also from SH and GD (Nilsson 1992b).

We have 25 specimens from three localities in AR (type series) and one in BA ranging in altitude from 2350 to $3450 \mathrm{~m}$ a.s.1. Most specimens were collected in small streams rich in vegetation.

\section{Agabus crypticoides Régimbart}

Agabus crypticoides Régimbart, 1895a: 152, 153.

This species was first described from Ethiopia, and our records are the first ones published since the original description (Nilsson 1992b).

We have 89 specimens from three localities in AR between 2350 and $2500 \mathrm{~m}$ a.s.l. Most specimens were collected in a stream near Bilalo, $5 \mathrm{~km} \mathrm{~S}$ of Asella, in late May and early July. A. crypticoides was most frequent where there was marginal vegetation or some organic debris on the bottom.

\section{Agabus abessinicus (Zimmermann)}

Gaurodytes abessinicus Zimmermann, 1928: 177, 178.

This species was described from Ethiopia, and it was long known only from the type series.
Guignot (1956d) mentioned a specimen from HA: Diredawa. A single female from the Ashilo River (Harrison \& Hynes 1988, station 27), a tributary to Wabe Shebela, at $2500 \mathrm{~m}$ a.s.l. in BA was seen in MZH.

\section{Agabus galamensis Nilsson}

Agabus galamensis Nilsson, 1992b: 174.

This species is endemic to Ethiopia, where it is known only from the type locality on Galama Mts. in AR (Nilsson 1992b). It was here collected in the outlet of a small lake at $3,100 \mathrm{~m}$ a.s.1.

\section{Genus Rhantus Dejean, 1833}

This is a large genus with almost 100 species, known from all major zoogeographical regions of the world. The 16 African species were reviewed by Guignot (1961).

\section{Rhantus includens (Walker)}

Colymbetes includens Walker, 1871: 11.

Rhantus elevatus Sharp, 1882: 609.

Rhantus pictiventris Régimbart, 1905: 208, 209.

Rhantus aulicus Omer-Cooper, 1931: $789+$ pl. 9:5.

This species occurs in Sinai, Arabia, Syria, Ethiopia and Nubia in Sudan (Balfour-Browne 1951, Guignot 1961:757). Brancucci (1984) recorded it from Saudi Arabia and showed that $R$. pictiventris is a junior synonym of $R$. includens. It was described from ER (Régimbart 1905), and later reported from SH (Régimbart 1922). OmerCooper (1931:789, as R. aulicus) reported on a long series from Mt. Zaquala at $2700 \mathrm{~m}$ a.s.l. in $\mathrm{SH}$.

\section{Rhantus longulus Régimbart}

Rhantus flavicollis Régimbart, 1887: 639 (not Eschscholtz, 1818).

Rhantus longulus Régimbart, 1895a: 181, syn. n.

Rhantus virosus J. Balfour-Browne, 1944: 354 (replacement name for Rhantus flavicollis Régimbart, 1887, not Eschscholtz, 1818).

This species is endemic to Ethiopia. It was first described from SH:Fallé (Régimbart 1887, as R. flavicollis), and later from Acachi and Lagagora (Régimbart 1895a). Omer-Cooper 
(1931:789) listed $R$. longulus from several localities in AR and $\mathrm{SH}$, at altitudes between 1650 and $2700 \mathrm{~m}$ a.s.l. Guignot $(1959 \mathrm{e})$ reported it from KA:Jimma, and Rocchi (1975a) provided a record from $\mathrm{SH}$ :Bargà.

We have 579 specimens of $R$. longulus from 19 different localities in $\mathrm{AR}, \mathrm{BA}$ and $\mathrm{SH}$, ranging in altitude from 2350 to $3100 \mathrm{~m}$ a.s.l. This is a very common species in AR highlands, that occurs in most types of both lentic and lotic waters (Figs. 4-6). The study of a large series has convinced us that the diagnostic characters given by Guignot (1961) for the separation of $R$. longulus and $R$. virosus only represent intraspecific variation. Two of our specimens were found identical with the material of $R$. virosus studied by Rocchi (1975a).

\section{Rhantus capensis (Aubé)}

Colymbetes capensis Aubé, 1838: 235.

This species is widespread in East and South Africa (Guignot 1961:762, Omer-Cooper 1965a:175). It was reported from Fallé in SH by Régimbart (1887), and later (Régimbart 1905, 1922) also from ER and a tributary to the River Akaki. Omer-Cooper (1931:788) listed $R$. capensis from many sites in AR and $\mathrm{SH}$, at altitudes from 1800 to $2600 \mathrm{~m}$ a.s.l. A record from SH:Bargà was provided by Rocchi (1975a). The aedeagus was illustrated by Omer-Cooper (1957:75, fig. 71).

We have 420 specimens of $R$. capensis from 19 different localities in $\mathrm{AR}$ and $\mathrm{SH}$, at altitudes between 2200 and $3100 \mathrm{~m}$ a.s.1. This species was very common in the AR highlands. It was frequently collected in both stagnant and running waters (Figs. 4-6).

\section{Subfamily Laccophilinae Gistel, 1856}

Genus Laccophilus Leach, 1815

This large genus has a worldwide distribution and includes more than 250 species. Guignot (1959b) recognized 66 species in Africa, of which 17 have been found in Ethiopia. The African species need to be revised.

\section{Laccophilus pictipennis Sharp}

Laccophilus pictipennis Sharp, 1882: 305.

Laccophilus discretus Sharp, 1882: 305.

Laccophilus restrictus Sharp, 1882: 315.

Laccophilus wehnckei Sharp, 1882: 306.

This rare species is known from Arabia to Zanzibar in Tanzania (Guignot 1959b:536). The only record from Ethiopia is that given by Sharp (1882:305). The aedeagus and habitus were illustrated by Brancucci (1979).

\section{Laccophilus laeticulus Régimbart}

Laccophilus laeticulus Régimbart, 1895a: 145 + fig. 61.

Guignot (1959b:538) listed this species from Guinea, Sierra Leone, Ivory Coast and Zaire. We have also seen specimens from Gambia (in coll. UML). The only Ethiopian record is from GO:Bahar Dar where it was collected at light in 1968 (in coll. SMNS).

\section{Laccophilus flavopictus Régimbart}

Laccophilus flavopictus Régimbart, 1889: 53.

This species was known with certainty only from Zaire, and records from Ethiopia, Kenya and Senegal were given with a question-mark by Guignot (1959b:543). A female from GO:Bahar Dar was seen in coll. SMNS and two specimens in MRAC are from SH:Sodere (leg. de Rougemont 1971).

We have three specimens from SI:Lake Awassa at $1600 \mathrm{~m}$ a.s.l. They were collected on 8.i.1989 in dense vegetation at the south lake margin near the hotel.

\section{Laccophilus grammicus Sharp}

Laccophilus grammicus Sharp, 1882: 306, 307.

This species was first described from Ethiopia (Sharp 1882), and later reported from ER (Régimbart 1905). Omer-Cooper (1931:759) listed it from $1800 \mathrm{~m}$ a.s.l. in SH. Records from other countries are uncertain as L. grammicus previously was confused with $L$. mutatus OmerCooper, 1970, which is the species described as L. grammicus by Guignot (1959b:548). 
We have a single male of L. grammicus from Dukkam, $35 \mathrm{~km} \mathrm{~S}$ of Addis Ababa at $2200 \mathrm{~m}$ a.s.l. It was collected in pools in a nearby dry stream.

\section{[Laccophilus lateralis Sharp}

Laccophilus lateralis Sharp, 1882: 307.

Laccophilus lateralis var. polygrammus Régimbart, 1903: 14.

This species was first described from Madagascar (Sharp 1882), and later Régimbart (1903) described the var. polygrammus from Madagascar and KA:Gimirra in South Ethiopia. OmerCooper $(1931: 757,758)$ reported on 77 specimens from $2700 \mathrm{~m}$ a.s.1. in $\mathrm{SH}$ as identical with Régimbart's specimens from Ethiopia. According to Balfour-Browne (1950:360), also her specimens of $L$. quindecimvittatus Régimbart from SH are in fact $L$. lateralis var. polygrammus. On the contrary, Guignot (1959b:552, 553) restricted the distribution of $L$. lateralis to Madagascar, assigned the Omer-Cooper specimens mentioned above to $L$. quindecimvittatus, and synonymized L. quindecimvittatus sensu Balfour-Browne with L. contiro Guignot.]

\section{Laccophilus quindecimvittatus Régimbart}

Laccophilus quindecimvittatus Régimbart, 1895a: $142+$ fig. 58 .

This species is endemic to Ethiopia. It was listed from a stream W of Mt. Zaquala at 1800 a.s.l. in SH by Omer-Cooper (1931:758). According to Guignot (1959b:553), also the specimens from Wouramboulchi at $2700 \mathrm{~m}$ a.s.l. listed by Omer-Cooper (1931:757) as L. lateralis var. polygrammus Régimbart belong to $L$. quindecimvittatus. It was collected at light in 1968 at GO:Bahar Dar (in coll. SMNS) and also known from KA and GG (MRAC).

This was the most frequently collected species of Laccophilus in the AR highlands, and we have 84 specimens from eight localities, ranging in altitude from 2350 to $2600 \mathrm{~m}$ a.s.l. A single record from $\mathrm{SH}$ is from $2350 \mathrm{~m}$ a.s.l. L. quindecimvittatus was collected in both lotic and lentic waters (Figs. 4, 5), but it was really abundant only in a densely vegetated part of the Ashabaka River, $10 \mathrm{~km} \mathrm{~S}$ of Sagure.

\section{Laccophilus contiro Guignot}

Laccophilus contiro Guignot, 1952b: 5, 6+ figs. 1b, 2b.

This species has a wide distribution in East and South Africa (Guignot 1959b:555, OmerCooper 1965a:78). It was described (Guignot 1952b) from the specimens from $2100 \mathrm{~m}$ a.s.l. at Mt. Chilalo in AR listed by Omer-Cooper (1931:758) as L. lineatus Aubé. Omer-Cooper (1.c.) had $L$. lineatus also from other localities, but according to Guignot (1959b:556) a part of this material belongs to $L$. adjutor Guignot.

\section{Laccophilus adjutor Guignot}

Laccophilus adjutor Guignot, 1950: 271.

This is an East African species. According to Guignot (1959b:556), a part of the material from Ethiopia listed by Omer-Cooper (1931:758) as $L$. lineatus in fact belongs to $L$. adjutor. It is not possible to say which localities represent $L$. adjutor, and which represent $L$. contiro (see above). As most of Omer-Cooper's localities are from SH, we have recorded $L$. adjutor from this province.

\section{Laccophilus remex Guignot}

Laccophilus remex Guignot, 1952c: 167.

Laccophilus turneri Omer-Cooper, 1957: 17 + figs. 14A, C, 15A-B.

This species was described from the Ivory Coast and later reported also from Zaire and Tanzania (Guignot 1959b:561). Omer-Cooper (1965a) recorded it also from Mocambique, Zimbabwe and South Africa. Three specimens were collected at light near IL:Gambela in Ethiopia (leg. Rybalov, coll. Hendrich).

\section{Laccophilus vitshumbii Guignot}

Laccophilus vitshumbii Guignot, 1959c: 161, 162 + fig. 13.

This species is known from Ethiopia, Uganda, Kenya, Malawi, Zimbabwe and Tanzania (OmerCooper 1970b). It was long confused with $L$. adspersus Boheman, and recorded under that name from ER (Régimbart 1905), and from several sites at 1650 to $2300 \mathrm{~m}$ a.s.l. in AR and SH (OmerCooper 1931:756, 757). Also the L. adspersus of Guignot (1959b:566) includes both species. Separating characters and illustrations of male genitalia 
were provided by Omer-Cooper (1970b:293, 294). It is also known from GO:Bahar Dar where it was collected at light in 1968 (in coll. SMNS) and 1973 (MRAC), and KA: $75 \mathrm{~km} \mathrm{SW}$ of Jimma (leg. Clarke 1972 MRAC).

We have three specimens of $L$. vitshumbii from two localities at 2200 and $2350 \mathrm{~m}$ a.s.l. in SH. It was collected in temporary ponds (Fig. 4), partly in an almost dry stream.

\section{Laccophilus evanescens Régimbart}

Laccophilus evanescens Régimbart, 1895a: 134, 135.

This species is distributed from Mauritania to Ethiopia, Zaire, Mozambique and Botswana (Guignot 1959b:568, Omer-Cooper 1965a:87, Bilardo \& Rocchi 1987:104). In Ethiopia known only from the delta of the River Omo in Lake Turkana, GG (Guignot 1946:278).

\section{Laccophilus modestus Régimbart}

Laccophilus modestus Régimbart, 1895a: 133.

This species is widespread in Africa south of the Sahara (Guignot 1959b:569, Omer-Cooper 1965a:87). The male genitalia were depicted by Omer-Cooper (1970b:293). The only Ethiopian records are from GO:Bahar Dar (at light in 1968 SMNS) and IL: Gambela (at light in 1972 MRAC).

\section{Laccophilus torquatus Guignot}

Laccophilus torquatus Guignot, 1956e: 320, 321 + fig. 1.

This species is widespread in tropical Africa (Omer-Cooper 1965a:80). It was described from Zaire, with some of the paratypes from KA:Bourillé in South Ethiopia.

\section{Laccophilus simplicistriatus Gschwendtner}

Laccophilus simplicistriaius Gschwendtner, 1935: 17+ fig. 1c. Laccophilus monas Guignot, 1953c: 238.

This species was long mixed up with other species, i.e. L. taeniolatus Régimbart and $L$. congener Omer-Cooper (Omer-Cooper 1965a: 82 ), and the distribution is therefore poorly known. It is seemingly widespread in East and South Africa. According to both Guignot (1959b: 571) and Omer-Cooper (1965a:81) a part of the material from Ethiopia listed by Omer-Cooper (1931:757) as L. taeniolatus in fact belongs to $L$. simplicistriatus. Known also from GO:Bahar Dar where it was collected at light in 1968 (SMNS). Specimens from GO and SH were also seen in coll. MRAC.

We have 19 specimens of $L$. simplicistriatus from five localities in AR, SH and SI, ranging in altitude from 1500 to $2350 \mathrm{~m}$ a.s.l. It was collected in lakes and ponds, both with dense or no vegetation. Note that the illustration of the aedeagus in Guignot (1959b:573) is fig. 515 and not 514 as stated in the legends. This species is best identified with the key in Omer-Cooper (1970b).

\section{Laccophilus taeniolatus Régimbart}

Laccophilus taeniolatus Régimbart, 1889: 52.

As this species was long confused with other species (see above) its distribution is not well known. According to Omer-Cooper (1970b:290), L. taeniolatus occupies the tropics and subtropics mainly north of the equator. Omer-Cooper (1931: 757) listed it from many localities in AR and $\mathrm{SH}$ in Ethiopia. However, a part of this material belongs to $L$. simplicistriatus. Judging from the available information (Omer-Cooper 1931:757, Guignot 1959b:575), specimens from at least Hora Shala, Hora Bishoftu and Djem Djem forest are L. taeniolatus, i.e. from 1500 to $2400 \mathrm{~m}$ a.s.l. in SH. It was also recorded from several regions in Ethiopia by Régimbart (1922), but these records may also refer to L. simplicistriatus. It was collected at light at IL:Gambela (leg. Rybalov, coll. Hendrich).

We have 31 specimens from four sites in $\mathrm{SH}$, ranging in altitude from 950 to $2200 \mathrm{~m}$ a.s.l. A single specimen was found at $2500 \mathrm{~m}$ a.s.l. in AR. Most specimens were collected in ponds with no or little vegetation (Figs. 1,2).

\section{Laccophilus inornatus Zimmermann}

Laccophilus inornatus Zimmermann, 1926: 24.

This species occurs from Guinea to Tanzania (Guignot 1959b:582). The only records from Ethiopia are from GO:Bahar Dar (at light in 1968 SMNS) and IL: Gambela (leg. de Rougemont 1972 MRAC). 
Laccophilus pellucidus Sharp

Laccophilus pellucidus Sharp, 1882: 304 + pl. 10:119.

Laccophilus ampliatus Régimbart, 1895a: 130, 131.

Laccophilus pilitarsis Régimbart, 1906: 247, 248.

This species is widespread in East and South Africa, from Ethiopia to the Cape (Omer-Cooper 1965a:88). It was recorded from three localities at 1500 and $2300 \mathrm{~m}$ a.s.1. in SH by Omer-Cooper (1931:756).

Genus Philodytes J. Balfour-Browne, 1939

This monobasic genus is confined to continental Africa.

\section{Philodytes umbrinus (Motschulsky)}

Laccophilus umbrinus Motschulsky, 1855: 83.

Laccophilus luridus Schaum, 1864: 107.

A widespread species of sporadic occurrence in most parts of Africa except for the north (Guignot 1959b:589, Omer-Cooper 1931:88). It was first described from Egypt. Two specimens from SH:Addis Ababa were seen in the Humboldt Museum, Berlin, and two from GG: 10-15 km S of Fegeg in MRAC (leg. de Rougemont 1974).

We have two specimens of $P$. umbrinus from Soddere, $65 \mathrm{~km} \mathrm{~N}$ of Asella, at $1500 \mathrm{~m}$ a.s.l. in $\mathrm{SH}$. It was here collected in a large temporary pond.

\section{Genus Neptosternus Sharp, 1882}

This genus includes about 35 species, chiefly in the Afrotropical and Indomalayan Regions (Franciscolo 1979). About 20 species occur in tropical Africa including Madagascar (OmerCooper 1970c). Species identification is very difficult and we have only identified two species. A few additional females from IL seen in MRAC may represent additional species.

\section{Neptosternus meridianus Omer-Cooper}

Neptosternus meridianus Omer-Cooper, 1970c: 66, fig. 1.

This species was described from South Africa, and we know of no published records from other regions. One male and one female from the Blue
Nile Gorge at $1100 \mathrm{~m}$ a.s.l. was seen in MRAC (1971, leg. Clarke). Presumably this site is in SH.

\section{Neptosternus sombuicus Guignot}

Neptosternus sombuicus Guignot, 1954: 6.

This species was previously known only from the type locality in Zaire (Omer-Cooper 1970c: 71). A single male was collected at light at IL:Gambela (1972, leg. Clarke MRAC).

\section{Subfamily Dytiscinae Leach, 1817}

\section{Genus Eretes Laporte, 1833}

A small genus with one species in Australia and one widespread species found in all other biogeographic regions (Franciscolo 1979:621).

\section{Eretes sticticus (Linnaeus)}

Dytiscus sticticus Linnaeus, 1767: 666.

Dytiscus griseus Fabricius, 1781: 293.

This species has an almost worldwide distribution and occurs throughout Africa (Guignot 1961:776). For a full list of synonyms see Guignot (1961:776) and Omer-Cooper (1965a:175, 176). It was reported from ER by Régimbart (1905) and Guignot (1959e), and Omer-Cooper (1931:794) listed a single specimen from $1500 \mathrm{~m}$ a.s.1. in SH. Specimens from IL, KA, GG and SI were seen in MRAC.

We have $E$. sticticus from three localities in $\mathrm{SH}$, ranging in altitude from 950 to $1500 \mathrm{~m}$ a.s.l. It was collected in more or less temporary stagnant waters with no or little vegetation (Fig. 2).

\section{Genus Hydaticus Leach, 1817}

This large genus has an almost worldwide distribution, with most of the about 150 species in the Old World tropics. Guignot (1961) reviewed the 60 African species that all belong to the subgenus Guignotites Brinck. So far, 14 species are known from Ethiopia.

\section{Hydaticus jeanneli Guignot}

Hydaticus jeanneli Guignot, 1936: 54, 55 + fig. 11B. Hydaticus wittei Gschwendtner, 1938b: 338-342. 
This is chiefly an East African species, known from some high-altitude regions in Kenya and Zaire (Guignot 1961:784), and also from Tanzania, Angola, Ngwane and South Africa (OmerCooper 1965ab). Guignot (1959e) recorded this species from KA:Jimma in Ethiopia. Three specimens collected near SH:Debra Berhan were seen in coll. MZH.

\section{Hydaticus exclamationis Aubé}

Hydaticus exclamationis Aubé, 1838: 235.

Hydaticus intermedius Régimbart, 1895a: 204.

Hydaticus exclamationis ab. interrogator Guignot, 1953d: 143.

This species is widespread in Africa south of the Sahara inclusive of Madagascar (OmerCooper 1965a:178). It was recorded from Ethiopia already by Régimbart (1895a), and later OmerCooper (1931:793, as $H$. intermedius) listed a single female from $2100 \mathrm{~m}$ a.s.l. in AR. OmerCooper (1965a:178) stated that it was reported also from ER by Régimbart, but we have not been able to verify this record. Guignot (1959e) recorded $H$. exclamationis from KA:Jimma.

\section{Hydaticus bivittatus Laporte}

Hydaticus bivitratus Laporte, 1835: 98.

Hydaticus bivittatus ab. sharpi Peschet, 1917: 45.

This species is widespread in Africa south of the Sahara inclusive of Madagascar (Guignot 1961:793, Omer-Cooper 1965a:179). The only Ethiopian record is from GO:Bahar Dar where it was collected at light in 1969 (in coll. SMNS).

\section{Hydaticus flavolineatus Boheman}

Hydaticus flavolineatus Boheman, 1848: 237.

This widespread species occurs in Arabia and in Africa except Sahara and the northernmost part (Guignot 1961:800, Omer-Cooper 1965a:179). It was reported from ER by Régimbart (1905), and Omer-Cooper (1931:790) listed it from $1800 \mathrm{~m}$ a.s.l. in SH. Three specimens from SI: Sidambale Bridge were seen in MRAC (leg. Clarke 1975).

We have a single specimen of $H$. flavolineatus from a large pond at $2500 \mathrm{~m}$ a.s.l. near Bilalo in AR.

\section{Hydaticus paganus Clark}

Hydaticus paganus Clark, 1864: 215, 216.

Guignot (1961:809) reported this species from Zaire, Ghana and Cameroun. From Ethiopia we have seen a single male from KA:Gembi near Agaro (in coll. MZH).

\section{Hydaticus dregei Aubé}

Hydaticus dregei Aubé, 1838: 172.

Hydaticus jucundus Reiche, 1850: 278, $279+$ pl. 16:7. Hydaticus nigromarmatus Clark, 1864: 220.

This species has a wide distribution in Arabia and East and South Africa (Omer-Cooper 1965a: 180, Rocchi 1984). It was described as H. jucundus from Ethiopia by Reiche (1850), and later reported from ER by Régimbart $(1904,1905)$. We have also seen specimens from $\mathrm{ER}$ in coll. $\mathrm{MZH}$.

\section{Hydaticus leander (Rossi)}

Dytiscus leander Rossi, 1790: 202.

Hydaticus nauzieli Fairmaire, 1859: LII.

This species belongs to a complex of very similar species that have been mixed up or confused by many previous authors. The distribution of $H$. leander is not accurately known, but includes at least South Europe, North Africa and parts of Asia (Guignot 1961:818, Omer-Cooper 1965a:183). It occurs probably also in West Africa, but older records from East Africa seemingly refer to other species. However, Wewalka (in litt.) has examined specimens of $H$. leander from GO:Bahar Dar, some of which we have seen in coll. SMNS and others in MRAC. Also known from IL: Gambela (leg. Clarke 1972 MRAC; leg. Rybalov 1984 SMNS). The $H$. leander of Omer-Cooper (1931:791) is probably H. basicollis Régimbart.

\section{Hydaticus basicollis Régimbart}

Hydaticus basicollis Régimbart, 1905: 226.

This species is seemingly endemic to Ethiopia. It was first described from SI:Lake Awassa (Régimbart 1905). Some of the specimens from SH listed by Omer-Cooper (1931:791) as H. leander, in fact belong to H. basicollis (Guignot 1961:819). As Omer-Cooper (1965a:183) suggested that $H$. leander 
does not occur in East Africa, it seems highly probable that all the specimens from $\mathrm{SH}$ are $H$. basicollis. If so, the altitudinal range was 1500 to $2400 \mathrm{~m}$ a.s.l. A single male from Addis Ababa was seen in the Humboldt Museum, Berlin, and additional specimens from SH in MRAC.

We have 21 specimens of $H$. basicollis from the margin of Lake Awassa, at $1600 \mathrm{~m}$ a.s.l. in SI. Some additional 10 specimens were collected in more or less temporary ponds at 950 and 1500 $\mathrm{m}$ a.s.l. in SH (Fig. 2).

\section{Hydaticus servillianus Aubé}

Hydaticus servillianus Aubé, 1838: 197.

Hydaticus discoidalis Hope, 1843: 364.

Hydaticus flavomarginatus Zimmermann, 1920: 228.

Hydaticus servillianus ineptus Guignot, 1953e: 2, 3.

This species has been confused with H. lean$d e r$, and the distribution is not well known. It is seemingly widespread in East and South Africa and occurs also on Madagascar (Omer-Cooper 1965a:183, 184). A single male from GG: Omo at $460 \mathrm{~m}$ a.s.l. was seen in MRAC (13.vii.1974 leg. de Rougemont). Also recorded from South Ethiopia (Gubala Ginda by the Sagan River) by Capra (1952).

\section{Hydaticus matruelis Clark}

Hydaticus matruelis Clark, 1864: 216.

Hydaticus matruelis var. fuscicollis Régimbart, 1895a: 197.

This species is common throughout tropical Africa, but rare to the south and not occurring on Madagascar (Omer-Cooper 1965a:182). It was recorded from Ethiopia by Zimmermann (1919: 227), and Omer-Cooper (1931:792) listed a single female from $2100 \mathrm{~m}$ a.s.l. in AR. Known also from IL:Gambela (leg. Rybalov 1984 SMNS), KA:Jimma (Guignot 1959e), SI: Sidambale Bridge (leg. Clarke 1975 MRAC), and from Addis Ababa (in coll. Humboldt Museum, Berlin) and Gibbie Gorge (MRAC) in SH.

\section{Hydaticus dorsiger Aubé}

Hydaticus dorsiger Aubé, 1838: 193.

This species is widespread in Africa south of the Sahara and occurs also in Arabia and on
Madagascar (Guignot 1961:829, Omer-Cooper 1965a:181). In SH, it is known from several localities ranging in altitude from 1650 to 2400 m a.s.l. (Omer-Cooper 1931:790; MRAC). Known also from KA:Jimma (Guignot 1959e), and GO:Bahar Dar (in coll. SMNS \& MRAC).

\section{Hydaticus abyssinicus Régimbart}

Hydaticus abyssinicus Régimbart, 1905: 225, 226.

Hydaticus nubivagus Omer-Cooper, 1931: 793 + pl. 9:4.

This species is endemic to Ethiopia. It was first described from "Gimirra" in KA (Régimbart 1905), and two female syntypes were seen in the Humboldt Museum, Berlin. Omer-Cooper (1931:793, as H. abyssinicus and H. nubivagus) listed it from three localities between 2300 and $2700 \mathrm{~m}$ a.s.l. in SH.

This is one of the commonest species in the AR highlands, from which we have 135 specimens from 11 localities ranging in altitude from 2350 to $3100 \mathrm{~m}$ a.s.l. A single specimen was also collected at $2600 \mathrm{~m}$ a.s.l. in SH. H. abyssinicus was collected in various stagnant or slowly running waters (Figs. 5, 6).

\section{Hydaticus galla Guérin-Méneville}

Hydaticus galla Guérin-Méneville, 1849: 268.

Hydaticus concinnaticius Wallengren, 1881: 14, 15.

Hydaticus nebulosus Régimbart, 1895a: 198.

Hydaticus galla var. taraxias Guignot, 1952d: 5.

This species was first described from Ethiopia (Guérin-Méneville 1849). It has a wide distribution in East and South Africa (Omer-Cooper 1965a:185). Régimbart (1887, 1895b) recorded it from $\mathrm{AR}$ and $\mathrm{SH}$, and later also from ER (Régimbart 1905) and GO (Régimbart 1922). Omer-Cooper (1931:792) listed it from several localities between 1800 and $2400 \mathrm{~m}$ a.s.l. in AR and SH. Known also from KA:Jimma (Guignot $1959 \mathrm{e})$ and from IL and SI (MRAC).

We have 88 specimens of $H$. galla from 8 localities between 2350 and $2600 \mathrm{~m}$ a.s.1. in AR. A single specimen is from $2,050 \mathrm{~m}$ a.s.1. in BA. $H$. galla was collected in various stagnant and slowly running waters (Figs. 3-5). 


\section{Hydaticus caffer Boheman}

Hydaticus caffer Boheman, 1848: 238.

This species is widespread in East and South Africa (Guignot 1961:839, Omer-Cooper 1965a:183). It was recorded from Ethiopia by Régimbart (1895a:201), and later also from ER (Régimbart 1905). We have seen two specimens from KA (in coll. MZH) and a male from SI: 80$88 \mathrm{~km}$ S of Dilla (leg. Clarke 1975 MRAC).

\section{Genus Rhantaticus Sharp, 1882}

A monobasic genus that is widespread in the Old World tropics.

\section{Rhantaticus congestus (Klug)}

Hydaticus congestus Klug, 1833: 136.

Hydaticus signatipennis Laporte, 1835: 95.

Hydaticus rochazi Montrouzier, 1865: 51.

This species is distributed from Africa to Australia. It is widespread in Africa south of the Sahara and also known from Madagascar (Guignot 1961:844, Omer-Cooper 1965a:186). It was first recorded from Ethiopia by OmerCooper (1931:795), who listed it from several localities between 1500 and $2300 \mathrm{~m}$ a.s.l. in SH. Known also from ER (Guignot 1959e) and KA (MRAC).

We have only two specimens from a pond in the lava-field at $950 \mathrm{~m}$ a.s.l. near Metahara in SH (Fig. 2).

\section{Genus Aethionectes Sharp, 1882}

A small genus with seven species confined to tropical Africa including Madagascar (Guignot 1961). We have only seen a single specimen from Ethiopia.

\section{Aethionectes apicalis (Boheman)}

Hydaticus apicalis Boheman, 1848: 239.

This species has a wide distribution in East and South Africa (Guignot 1961:847, OmerCooper 1965a:186). From Ethiopia a single male was seen from Sidamo, $10 \mathrm{~km}$ NW of Neghelli, $1550 \mathrm{~m}$ a.s.1. (14.v.1975 leg. Clarke MRAC).

\section{Genus Cybister Curtis, 1827}

This is a large genus with about 100 species, chiefly confined to the Old World tropics. Only few species occur in South and North America. Guignot (1961) reviewed the 48 African species, of which eight have been recorded from Ethiopia.

\section{Cybister vulneratus Klug}

Cybister vulneratus Klug, 1834: 33.

Cybister binotatus Klug, 1835: 28.

Cybister bivulneratus Aubé, 1838: 91.

Cybister madagascarensis Aubé, 1838: 94.

This species occurs in the Mediterranean region, Arabia, the whole of Africa and on Madagascar and Mauritius (Guignot 1961:872, OmerCooper 1965a:188). In Ethiopia, it was recorded from SH by Régimbart (1887), and later from SI:Laka Abaya (Régimbart 1922). Known also from KA:Jimma (Guignot 1959e) and Agaro (in coll. MZH).

We have two females from SI:Lake Awassa at $1600 \mathrm{~m}$ a.s.l., where it was collected among dense vegetation at the lake margin.

\section{Cybister pinguis Régimbart \\ Cybister pinguis Régimbart, 1895a: 220.}

This species was first described from Somalia (Régimbart 1895a:220). Guignot (1961:896) recorded it also from East Africa and Senegal. A single female from Ethiopia is from IL:Gambela, 25 km SE Abobo (25.xii.1984 leg. Rybalov SMNS).

\section{Cybister marginicollis Boheman}

Cybister marginicollis Boheman, 1848: 235.

Cybister auritus Gerstaecker, 1871: 43.

Cybister filicornis Sharp, 1882: 719.

Cybister marginicollis annulicornis Griffini, 1898: 2.

This species is widely distributed in Africa south of the Sahara. Specimens from Madagascar are often assigned to a separate species, C. auritus (e.g. Guignot 1961:899), but we have followed the synonymy proposed by Omer-Cooper (1965a:192, 193). The only Ethiopian record is from KA:Jimma (Guignot 1959e). 
Cybister senegalensis Aubé

Cybister senegalensis Aubé, 1838: 72.

Cybister convexiusculus Kolbe, 1883: 420.

Cybister senegalensis var. irroratus Kolbe, 1883: 420.

Cybister senegalensis var, seidlitzi Ragusa, 1887: 43.

Cybister marginellus Régimbart, 1895a: 212.

Cybister rufiventris Régimbart, 1895a: 214.

This widespread species occurs in the Mediterranean Region and in the whole of Africa south to the Transvaal (Omer-Cooper 1965a:196). As three very similar species were described after 1930 , older records are not reliable. From Ethiopia, we know only the record from SI:Lake Abaya given by Régimbart (1922). This record needs verification as it could refer to $C$. alluaudi Guignot. The record of $C$. alluaudi from Ethiopia given by Rocchi (1975a) is however due to a printer's error (Rocchi, in litt.).

\section{Cybister reichei Aubé \\ Cybister reichei Aubé, 1838: 79-81.}

This species is widespread in North, East and Central Africa (Guignot 1961:907). According to Omer-Cooper (1965a:198), the aedeagal illustrations of C. reichei and C. natalensis (Wehncke) were mixed up by Guignot (l.c.). Three males from Ethiopia are from IL:Gambela, $30 \mathrm{~km} \mathrm{~W}$ Abobo (20.vii.1984 leg. Rybalov SMNS).

\section{Cybister tripunctatus (Olivier)}

Dytiscus tripunctatus Olivier, 1795: 14.

Dytiscus lateralis Fabricius, 1798: 64.

Cybister africanus Laporte, 1835: 99.

This widespread species ranges over the warmer parts of the Old World. For a full list of synonyms see Guignot (1961:912) and OmerCooper (1965a:194). Populations from the African mainland belong to the subspecies $C . t$. africanus Laporte. In Ethiopia, it was recorded from SH by Régimbart (1887), and from ER by Régimbart (1905) and Guignot (1959e). OmerCooper (1931:795) listed it from four localities between 1500 and $2300 \mathrm{~m}$ a.s.l. in SH. Known also from the Akaki River (Rocchi 1975a), and from SI:Borana (Capra 1952).

We have 14 specimens from three localities at 950 to $1500 \mathrm{~m}$ a.s.l. in SH. It was collected in more or less temporary ponds (Fig. 2) and in a lagune by the Awash River.

\section{Cybister gschwendtneri Guignot}

Cybister regimbalti Gschwendtner, 1931: 98 (not Wilke, 1919).

Cybister gschwendmeri Guignot, 1935: 38 (replacement name for Cybister regimbarti Gschwendtner, 1931, not Wilke, 1919).

This species was long mixed up with $C$. tripunctatus, so that the distribution is not exactly known. It is seemingly widespread in Africa south of the Sahara (Guignot 1961:915, Omer-Cooper 1965a:195). In Ethiopia, it was recorded from Degagollo and Bogol Magno in the south (Capra 1952), and later also from ER (Guignot 1959e).

\section{Cybister cephalotes Sharp \\ Cybister cephalotes Sharp, 1882: 737, 738.}

This species was first described from "Lebka, Bogos" in Eritrea (Sharp 1882). It is now known also from Sudan, Arabia and maybe also Egypt (Balfour-Browne 1951:194). Gschwendtner (1927) described the var. konduensis from Zaire, but this is probably another species (cf Guignot 1961:918).

\section{Discussion}

The 168 species of Dytiscidae recorded from Ethiopia could be compared with the 147 species found in Sweden (Nilsson \& Persson 1989), which has an area that is about $2 / 3$ smaller than that of Ethiopia. However, the expected number of species is certainly higher for Ethiopia, as the collecting intensity has been very low. The number of genera are 29 for Ethiopia and 28 for Sweden, with 10 genera represented in both regions. However, the faunal differences are striking when the diversity of individual genera is looked at. Mainly tropical genera like Hydroglyphus, Hyphydrus, Hydrovatus, Copelatus, Laccophilus, Hydaticus and Cybister are wellrepresented in Ethiopia, whereas mainly Holarctic genera like Hydroporus, Ilybius and Dytiscus are absent, or like Agabus represented by comparatively few species. 


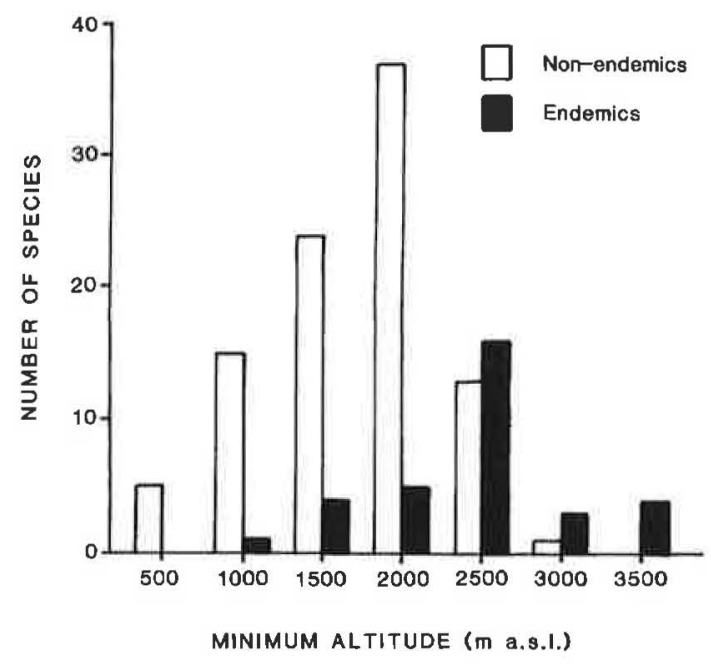

Fig. 8. Lower altitudinal limits of endemic and nonendemic species of Dytiscidae in Ethiopia. Data from Table 1; class limits are: $0-500,501-1000$ etc.

The Ethiopian dytiscid fauna has a high proportion of endemic species, i.e. 38 out of 168 species have not been found outside Ethiopia. As noted by Mani (1968:171), the proportion of endemic species increases with altitude, and few endemics have been found below $2000 \mathrm{~m}$ a.s.l. (Fig. 8). Consequently, the proportion of endemic species is high in GD, SH, AR and BA (Fig. 9), where the highest mountains are situated. No genus of Dytiscidae is endemic to Ethiopia, but it could be that some species groups, like the Nebrioporus abyssinicus-group (Nilsson 1992a), are largely concentrated to the Ethiopian highlands.

The number of species recorded from each locality ranged from 1 to 22 , and the number of individuals from 1 to 1200 . Looking only at the 14 localities where more than 100 individuals were collected it is clear that species richness is largely a function of collecting effort, i.e. number of individuals collected (Fig. 10, $r=0.82, P<$ 0.001 ). The relation between collecting effort and number of individuals collected is not known. As collecting effort varied strongly between sites, few individuals may either reflect low density or low collecting effort.

Generally, both species diversity and abundance are highest at intermediate elevations in

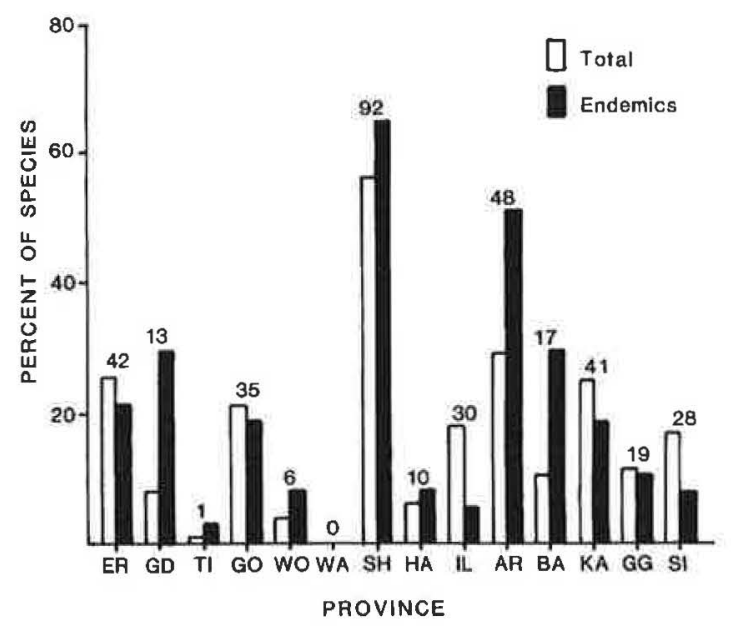

Fig. 9. Proportions of all species and of species of Dytiscidae endemic to Ethiopia recorded from each province (abbreviated as in Fig. 7). Numbers above bars give the number of species known from each province.

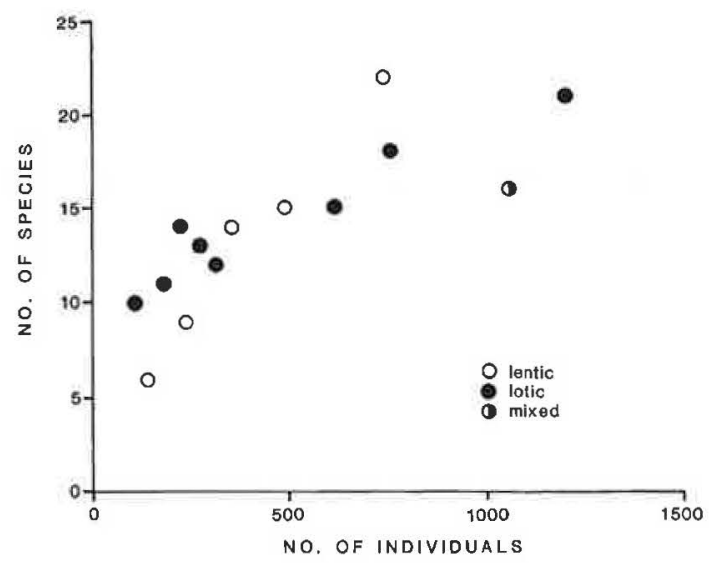

Fig. 10. Relationship between number of individuals and number of species found in samples with more than 100 individuals from localities between 2350 and $3100 \mathrm{~m}$ a.s.l. in the Arssi province. Lentic and lotic sites are separated, and one site included both kinds of habitats.

the tropics (Janzen et al. 1976). For this set of localities there is no correlation between altitude and number of species. However, when the four localities with more than 700 individuals are compared it seems that the 16 species recorded at 
$3100 \mathrm{~m}$ a.s.l. reflect a lower species diversity than at $2350-2600 \mathrm{~m}$.

There is no evident difference in diversity between lentic and lotic sites, and many species occurred in both kind of habitats. The most diverse site that had 22 species was a small man-made temporary pond in Eucalyptus forest near Asella at $2350 \mathrm{~m}$ a.s.l. This pond had a diameter of about $3 \mathrm{~m}$ and a depth of $0.5 \mathrm{~m}$. The bottom was covered with detritus. This pond was visited four times in September and October 1988 yielding 736 specimens. In a small stream $5 \mathrm{~km} \mathrm{~S}$ of Asella at $2500 \mathrm{~m}$ a.s.1. the 1200 collected specimens represented 21 species. This site was visited eight times.

Our results indicate that the maximum species richness in both ponds and streams above 2000 $m$ a.s.l. is near 20 species. In boreal Sweden, the maximum local species diversity of ponds could be slightly higher, whereas that of streams is much lower (Nilsson, unpublished).

The material from the Arssi highlands (2350$3100 \mathrm{~m}$ a.s.l.) provides some information on species richness of genera, tribes and subfamilies, and species co-occurrence patterns. At two sites, ten species of Hydroporinae were found together. The maximum number of species of Bidessini was five, recorded at four sites. At two of these sites four species of Hydroglyphus co-occurred, viz. $H$. infirmus, $H$. milkoi, $H$. sordidus, and $H$. fufai. All three species of Nebrioporus found in this region were collected together at two sites.

The maximum number of species of Colymbetinae (incl. Copelatini) at one site was nine, and the local diversity of this subfamily spanned a similar range as that of Hydroporinae. In most samples, Copelatus ragazzii was the only species of the genus, but at one site four Copelatus-species co-occurred, viz. C. erichsoni, C. atrosulcatus, C. ragazzii, and C. aethiopicus.

The local distributions of Agabus pallidus and $A$. raffrayi have been documented in detail earlier (Nilsson \& Persson 1990), and these two species co-occurred at most with one other congeneric species. Rhantus longulus and $R$. capensis co-occurred at most sites, as did Hydaticus abyssinicus and $H$. galla. At one site only, the maximum number of three species of Dytiscinae (all Hydaticus) was recorded.
Laccophilinae was in the Arssi highlands at most sites represented by $L$. quindecimvittatus only. At a few sites it co-occurred with $L$. simplicistriatus or L. taeniolatus.

A study of the material from the 16 Arssi sites with more than 30 specimens collected provide some interesting information on the relationship between rare and frequent (at eight or more sites) species in different genera. No species of Bidessus, Uvarus or Yola were frequent. On the contrary, Hydroglyphus had three frequent species in the area. The genera with mediumsized species Herophydrus, Hyphydrus, Nebrioporus, Laccophilus and Copelatus each had only one frequent species and 1-3 rare ones. On the other hand, the three genera with the largest bodysize, Agabus, Rhantus and Hydaticus, each had two frequent species in the region.

Information of the kind presented above is hard to find in literature, and consequently comparisons between different faunas cannot be made for the moment. Such an analysis could provide new insight into the structure of tropical highaltitude communities and faunas.

Acknowledgements. Dr O. Biström, Helsinki, is thanked for valuable help in identifying species, lending us material and making distributional data available. Dr G. Wewalka, Vienna, has kindly helped us with species identification and provided much distributional data. Dr. A. Bilardo, Varese, has kindly helped us with species identification. Mr M. Balke, Berlin, Dr M. Brancucci, Basel, and Dr S. Rocchi, Firenze, all gave valuable information. Dr J. Decelle, Tervuren, Dr F. Hieke, East Berlin, Mr P. Lindskog, Stockholm, Dr R. Poggi, Genova, and Dr W. Schawaller, Stuttgart, are thanked for sending us museum specimens.

\section{References}

Alwarth (=Ahlwarth), K. 1921: Coleoptera. Dytiscidae, Gyrinidae. - Wiss. Ergebn. Deutsch. Zentr. Afr. Exp. 5. Zool. 3(5):441-447.

Ancey, C. F. 1883: Contributions à la faune de l'Afrique Orientale. Descriptions de Coléoptères nouveaux. 2. - Naturalista Sicil. 2(1882):68-72, 94 96, 116-120.

Aubé, C. 1838: Hydrocanthares et Gyriniens. - - In: Dejean, A., Species géneral des Coléoptères de la collection de M. le Comte Dejean. 6. Paris.

Babington, C. C. 1841: Dytiscidae Darwinianae. - Trans. R. Entomol. Soc. London 3:1-17+1 pl. 
Balfour-Browne, J. 1939a: Scientific results of the Cambridge Expedition to the East African Lakes, 1930-1. XIX, Coleoptera of the families Dytiscidae and Gyrinidae. - J. Linn. Soc. 40:475-485.

- 1939b: On Copelatus Er. and Leiopterus Steph. (Col. Dytiscidae) with descriptions of new species. - Trans. R. Entomol. Soc. London 88:57-88.

- 1944: New names and new synonymies in the Dytiscidae (Col.). — Ann. Mag. Nat. Hist. (11)11:345 359 .

- 1947: New and interesting aquatic Coleoptera from the Sudan. - Proc. Entomol. Soc. London (B) 16:133142 .

- 1950: On the aquatic Coleoptera of Northern Rhodesia (Dytiscidae, Gyrinidae and Palpicomia). - Occ. Pap. Nat. Mus. Sth. Rhodesia 2(16):359-401.

- 1951: Coleoptera: Haliplidae, Dytiscidae, Gyrinidae, Hydraenidae, Hydrophilidae. - Exp. South-West Arabia 1(16):179-220 + pls. 10, 11.

Bilardo, A. \& Pederzani, F. 1972: Contributo alla conoscenza dei Copelatus Er. africani con descrizione di quattro nuove specie (Coleoptera Dytiscidae). - Mem. Soc. Entomol. Ital. 51:71-87.

- 1978: Récoltes de coléoptères aquatiques Haliplidae et Dytiscidae dans le Gabon et la Côte d'Ivoire. Mem. Soc. Entomol. Ital. 56(1976-77):93-130.

- 1979: Descrizione di quatro nuove specie et di tre allotipi di Coleoptera Dytiscidae africani. - Revue Zool. Bot. Afr. 93:766-774.

Bilardo, A. \& Rocchi, S. 1987: Contributo alla conoscenza degli Haliplidae e dei Dytiscidae del Botswana (Coleoptera). -- Atti Soc. Ital. Sci. Nat. 128:85-106 + pl. 1-4.

-- 1990: Haliplidae e Dytiscidae (Coleoptera) del Gabon con note sistematiche sulle specie di confronto (Parte prima: Haliplidae, Methlinae, Hydroporinae, Noterinae, Laccophilinae). — Atti Soc. Ital. Sci. Nat. 131:157196.

Biström, O. 1979: A revision of the genus Derovatellus Sharp (Coleoptera, Dytiscidae) in Africa. - Acta Entomol. Fennica 35:1-28.

- 1982: A revision of the genus Hyphydrus Illiger (Coleoptera, Dytiscidae). - Acta Zool. Fennica 165:1121.

- 1983a: Revision of the genera Yola Des Gozis and Yolina Guignot (Coleoptera, Dytiscidae). - Acta Zool. Fennica 176:1-67.

- 1983b: New records of Hyphydrus and Derovatellus, with descriptions of two new Hyphydrus species (Coleoptera, Dytiscidae). - Ann. Entomol. Fennici 49:117-121.

- 1984a: Bidessus species (Coleoptera, Dytiscidae) from Africa, with the description of Bidessus excavatus n.sp. - Entomol. Basil. 9:75-79.

- 1984b: Notes on the genus Hyphydrus, with description of H. imitator sp.n. (Coleoptera, Dytiscidae). - Ann. Entomol. Fennici 50:51-54.
- 1985: A revision of the species group B. sharpi in the genus Bidessus (Coleoptera, Dytiscidae). - Acta Zool. Fennica 178:1-40.

- 1986a: Review of the genus Hydroglyphus Motschulsky (= Guignotus Houlbert) in Africa (Coleoptera, Dytiscidae). - Acta Zool. Fennica 182:1-56.

- 1986b: Derovatellus intermedius sp.n., and notes on the genus in the Omer-Cooper collection (Coleoptera, Dytiscidae). - Ann. Entomol. Fennici 52:44-45.

- 1987: Review of the genus Leiodytes in Africa (Coleoptera, Dytiscidae). - Ann. Entomol. Fennici 53:91-101.

- 1988a: Review of the genus Uvarus Guignot in Africa (Coleoptera, Dytiscidae). — Acta Entomol. Fennica 51:1-38.

- 1988b: Revision of the genus Clypeodytes Régimbart in Africa (Coleoptera: Dytiscidae). - Entomol. Scand. 19:199-238.

- 1988c: Generic review of the Bidessini (Coleoptera, Dytiscidae). - Acta Zool. Fennica 184:1-41.

- 1988d: Bidessus bertrandi sp.n., and faunistic notes on the genus from Africa (Coleoptera, Dytiscidae). Ann. Entomol. Fennici 54:29-31.

Biström, O. \& Nilsson, A. N. 1990: Hydroglyphus perssoni sp. n. and Bidessus perssoni sp. n., described from Ethiopia (Coleoptera, Dytiscidae). — Aquat. Insects 12:181-184.

Biström, O. \& Sanfilippo, N. 1986: Bidessus apicidens sp.n., and faunistic notes on the genus from Africa (Coleoptera, Dytiscidae). - Ann. Entomol. Fennici 52:46-47.

Boheman, C. H. 1848: Insecta Caffraria annis 1838-1845 a J.A.Wahlberg collecta. 1(1). Coleoptera (Carabici, Hydrocanthari, Gyrinii et Staphylinii). - Holmiae.

Borre, P. de. 1870: Description d'une nouvelle espèce du genre Hyphydrus. - Ann. Soc. Entomol. Belg. 14:X$\mathrm{XI}$.

Brancucci, M. 1979: Insects of Saudi Arabia. Coleoptera: Fam. Haliplidae, Dytiscidae, Gyrinidae. - Fauna of Saudi Arabia 1:156-161.

- 1980: Insects of Saudi Arabia. Coleoptera: Fam. Haliplidae, Dytiscidae, Gyrinidae. Part 2. - Fauna of Saudi Arabia 2:102-111.

-- 1984: Insects of Saudi Arabia. Coleoptera: Fam. Haliplidae, Noteridae, Dytiscidae, Gyrinidae (Part 4). — Fauna of Saudi Arabia 6:229-242.

Bruneau de Miré, P. \& Legros, C. 1963: Les coléoptères Hydrocanthares du Tibesti. - Bull. Inst. Fr. Afr. Noire (A) 25:838-894.

Capra, F. 1952: Appendice. - Doriana 1(29):6-8.

Clark, H. 1864: Notes on the genus Hydaticus (Leach), with descriptions of new species. - Trans. R. Entomol. Soc. London (3)2:209-222 + pl 14

Derksen, W. \& Scheiding, U. 1963: Index Literaturae Entomologicae. Serie 2. Band 1. Deutsche Akademie der Landwirtschaftswissenschaften, Berlin.

Erichson, W. F. 1843: Beitrag zur Insecten Fauna von Angola in besonderen Beziehung zur geographischen 
Verbreitung den Insecten in Afrika. - Arch. Naturgesch. 9:199-267.

Fabricius, J. C. 1781: Species Insectorum. 1. - Hamburgi et Kilonii.

- 1798: Supplementum entomologiae systematicae. Hafniae.

Fairmaire, L. 1859: Description de quelques nouveaux Coléoptères de France. - Ann, Soc. Entomol. Fr. (3) 7:LII.

- 1869: Notes sur les Coléoptères recueillis par Ch. Coquerel à Madagascar et sur les côtes d'Afrique. Ann. Soc. Entomol. Fr. (4) 9:179-260.

- 1880: Descriptions de Coléoptères nouveaux du nord de l'Afrique. 4. - Ann. Soc. Entomol. Fr. (5) 10:245-252.

Franciscolo, M. E. 1966: Notes on Iberian Dytiscoidea, I: Methlinae Guignot, 1936, a subfamily of Dytiscidae (Coleoptera) apparently new to Europe. - Proc. R. Entomol. Soc. London (B) 35:11-15.

- 1979: Coleoptera, Haliplidae, Hygrobiidae, Gyrinidae, Dytiscidae. - Fauna d'Italia 14:1-804.

Franciscolo, M. E. \& Sanfilippo, N. 1986: Gyrinidae and Dytiscidae collected in Sierra Leone $(1982,1983,1984)$ by Dr. W. Rossi (Col. Hydradephaga). - Richerche biologiche in Sierra Leone 2:1 1-36+ 1 pl.

Germar, E. F. 1838: Fauna Insectorum Europae. 20. Halae.

Gerstaecker, C. E. A. 1871: Beitlag zur Insecten-fauna von Zanzibar. 3. Coleoptera, - Arch. Naturgesch. $37: 42-86$

Griffini, A. 1898: Sui Cybister raccolti dal Rev. H. Junod a Delagoa. - Boll. Musei Zool. Anat. Comp. R. Univ. Torino 12:1-6.

Gschwendtner, L. 1927: Neue und Neues aus den Familien der Haliplidae und Dytiscidae. - Bull. Mens. Soc. Nat. Luxemb. 37:91-94.

- 1930: Schwimmkäfer aus Belgisch Kongo, - Revue Zool. Bot. Afr. 19:208-223.

- 1931: Revision der Cybister tripunctatus-Gruppe. Entomol. B1. Biol. Syst. Käfer 27:65-70, 99-104.

- 1932: Neue Schwimmkäfer aus Belgisch Kongo. 2. Revue Zool. Bot. Afr. 22:259-268.

- 1933: Neue Schwimmkäfer aus Belgisch Kongo. IV Teil. — Revue Zool. Bot. Afr. 23:84-99.

- 1935: Wissenschaftliche Ergebnisse der Vernay-Lang Kalahari Expedition, Mäız bis September 1930. Haliplidae et Dytiscidae. — Ann. Transv. Mus. 17:1525.

- 1938a: Haliplidae und Dytiscidae. - Expl. Parc Nat. Albert Miss. De Witte 13:3-32.

- 1938b: Neue Dytiscidae aus Belgische Congo. - Revue Zool. Bot. Afr. 30:338-342.

- 1943: Neue Dytiscidae aus Belgisch Kongo. — Revue Zool. Bot. Afr. 36:417-426.

Guérin-Méneville, F. E. 1849: Insectes. - In: Lefebvre, C. T. (ed.), Voyage en Abyssinie execute pendant les années 1839-43. Zool. 6(4):239-390 + 12 pl. Paris.

Guéorguiev, V. B. 1968: Essai de classification des Coléoptères Dytiscidae. I. Tribus Copelatini (Colymbetinae). - Izv. Zool. Inst. Sofia 28:5-45.
Guignot, F. 1935: Douzième note sur les Hydrocanthares. - Bull. Soc. Entomol, Fr. 1935:36-40.

- 1936: Mission scientifique de l'Omo 4(31). Coleoptera. 10. Haliplidae et Dytiscidae (1 re partie). - Mém. Mus. Nat. Hist. Nat. Paris 8(1938): 1-76.

- 1939: Contribution à l'étude des Bidessus. - Bull. Soc. Etud. Sci. Nat. Vaucluse 10:51-61.

- 1940: Description de nouveaux Dytiscidae d'Afrique. - Bull. Soc. Etud. Sci. Nat. Vaucluse 11:31-39.

- 1942: Diagnoses préliminaires de nouveaux dytiscides africains. - Bull. Soc. Etud. Sci. Nat. Vaucluse 13:1215.

- 1945: Dix-neuvième nole sur les Hydrocanthares. Bull. Soc. Etud. Sci. Nat. Vaucluse 14(1943):5-9.

- 1946: Mission scientifique de l'Omo 6(58). Coleoptera Dytiscidae 2. - Mém. Mus. Nat. Hist. Nat. Paris 19(1945):215-322.

- 1947: Vingt-et-unième note sur les Hydrocanthares. - Bull. Soc. Entomol. Fr. 1947:12-16.

- 1948: Vingt-sixième note sur les Hydrocanthares. Dytiscides et Gyrinides nouveaux ou peu connus du Congo belge. - Bull. Mus. R. Hist, Nat. Belg. 24(12):1-14.

- 1950: Trente quatrième note sur les Hydiocanthares. — Entomol. Arb. Mus. Georg Frey 1:270-272.

- 1952a: Description de Dytiscides inédits de la collection Régimbart. - Revue Fr. Entomol. 19:17-31.

- 1952b: Description de nouveaux dytiscides Africains. — Bull. Inst. R. Sci. Nat. Belg. 28(17):1-7.

- 1952c: Description de Dytiscides inédits de la collection Régimbart et de quelques autres espèces et variétés nouvelles. - Revue Fr. Entomol. 19:166-171.

- 1952d: Nouveaux dytiscides du Parc National de l'Upemba. - Bull. Inst. R. Sci. Nat. Belg. 28(22):1-6.

- 1953a: Hydrocanthares capturés à la lumière dans le Haut Katanga. - Revue Zool. Bot. Afr. 47:233-237.

- 1953b: Nouveaux dytiscides du Parc National de l'Upemba. Diagnosis provisoires (suite)(1), - Bull. Inst. R. Sci. Nat. Belg. 29(18):1-4.

- 1953c: Dytiscides nouveaux de l'Ituri, du Kivu et du Ruanda-Urundi. - Revue Zool. Bot. Afr. 47:238-240.

- 1953d: Description de deux dytiscides africains. Revue Zool. Bot. Afi, 48:142-143.

- 1953e: Nouveaux dytiscides du Parc National de l'Upemba. Diagnoses provisoires. - Bull. Inst. R. Sci. Nat. Belg. 29(29): 1-3.

- 1954: Nouveaux dytiscides du Parc National de l'Upemba. Diagnoses provisoires (suite et fin). — Bull. Inst. R. Sci. Nat. Belg. 30(9):1-8.

- 1955a: Contribution à l'étude du peuplement de la Mauritanie. Dytiscides (2e note). - Bull. Inst. Fr. Afr. noire (A) 17:859-866

- 1955b: Dytiscides nouveaux du Musée Royal du Congo Belge. - Revue Zool. Bot. Afr. 52:1-7.

- 1956a: Contribution à la connaissance de la fauna Malgache. - Naturaliste Malgache 7:75-80.

- 1956b: Dytiscidae nouveaux du Congo belge. - Bull. Ann. Soc. R. Entomol. Belg. 92:249-256. 
— 1956c: Coléoptères Dytiscides et Gyrinides du Soudan francais. - Bull. Inst. Fr. Afr. Noire (A) 18:83-92.

- 1956d: Dytiscidae nouveaux ou intéressants du Musée National d'Histoire Naturelle de Budapest. - Ann. Hist.-Nat. Mus. Nat. Hung. 48:395-399.

- 1956e: Hydrocanthares capturés à la lumière au Congo belge. - Revue Zool. Bot. Afr. 53:317-323.

- 1957: Dytiscides et gyrinides de l'ile de la Réunion. - Mém. Inst. Sci. Madagascar 8:97-101.

- 1958: Haliplidae et Dytiscidae nouveaux du parc national de la Garamba. Deuxieme serie. - Bull. Inst. R. Sci. Nat. Belg. 34(6):1-8.

- 1959a: Revision des Hydrocanthares d'Afrique (Coleoptera Dytiscoidea. 1. - Ann. Mus. R. Congo Belge Sér. 8vo (Sci. Zool.) 70:1-313.

- 1959b: Revision des Hydrocanthares d'Afrique (Coleoptera Dytiscoidea). 2. - Ann. Mus. R. Congo Belge Sér. 8vo (Sci. Zool.) 78:323-648.

- 1959c: Haliplidae et Dytiscidae (Coleoptera Hydrocanthares). - Résult. Sci. Explor. Hydrobiol. Lacs Kivu, Edouard et Albert 3(1957)(2):133-169.

- 1959d: Nouveaux dytiscides du Musée Royal du Congo belge. - Revue Zool. Bot. Afr. 59:228-232.

- 1959e: Dytiscidae et Gyrinidae de l'Afrique orientale du Musée civique d'histoire naturelle de Milan. Atti. Soc. ital. Sci. Nat. 98:355-359.

- 1961: Revision des Hydrocanthares d'Afrique (Coleoptera Dytiscoidea). 3. - Annls Mus. R. Congo belge Sér. 8vo (Sci. Zool.) 90:659-995.

Harrison, A. D. \& Hynes, H. B. N. 1988: Benthic fauna of Ethiopian mountain streams and rivers. - Arch. Hydrobiol., Suppl. 81:1-36.

Hope, F. W. 1843: On some new insects from Western Africa. - Ann. Mag. Nat. Hist. 11:364-369.

Jackson, D. J. 1956: Dimorphism of the metasternal wings in Agabus raffrayi Shatp and A. labiatus Brahm (Col., Dytiscidae) and its relation to capacity for flight. Proc. R. Entomol. Soc. London A31:1-11.

Janzen, D. H., Ataroff, M., Fariñas, M., Reyes, S., Rincon, N., Soler, A., Soriano, P. \& Vera, M. 1976: Changes in the arthropod community along an elevational transect in the Venezuelan Andes, - Biotropica 8:193-203.

Klug, J. C. F. 1833: Bericht über eine auf Madagascar veranstaltete Sammlung von Insecten aus der Ordnung Coleoptera. - Berlin.

- 1834: Symbolae physicae. 4. - Berolini.

- 1835: Verzeichnis von Thieren und Pflanzen, welche auf einer Reise um die Erde gesammelt wurden, - In: Erman, A. (ed.), Reise um die Erde durch Nord-Asien und die beiden Oceanien in den Jahren 1828, 1829 und 1830. Berlin.

Kolbe, H. J. 1883: Über die madagascarischen Dytisciden des Königl. Entomol. Museums zu Berlin. - Arch. Naturgesch. 49(1):367-427.

Kunze, G. 1818: Entomologische Fragmente, - Neue Schrift. Nat. Ges. Halle 2(4): 1-76.

Laporte, F. L. 1834-1835: Études entomologiques. Première partie. - Paris.
Legros, C. 1958: Coléoptères Hydrocanthares. 9. La Réserve naturelle intégrale du Mont Nimba (Mission M. Lamotte et Roy,juillet-décembre 1951).4. — Mém. Inst. Fr. Afr. Noire 53:209-218.

Leprieur, C.-E. 1879: Hydrovatus Aristidis (sp. nov.). Ann. Soc. Entomol. Fr. (5) 9, Bull. LXXXII-LXXXIII.

- 1880: Séance du 11 Février 1880. - Ann. Soc. Entomol, Fr. (5) 10, Bull. XXV.

Linnaeus, C. 1767: Systema Naturae (ed. 12). 1(2):5331327. - Holmiae.

Mani, M. S. 1968: Ecology and biogeography of high altitude insects. - Dr. W. Junk Publ. The Hague.

Montrouzier, X. 1865: Essai sur la fauna entomologique de quelques espèces nouvelles ou peu connues. Ann. Soc. Linn. Lyon 10(1864):46-256 + 1 pl.

Motschulsky, V. de. 1855: Nouveautés. - Etud. Entomol. 4:82-84.

Nilsson, A. N. 1991a: On the genus Canthyporus Zimmermann (Coleoptera, Dytiscidae), with a new species from the highlands of Ethiopia. - Aquatic Insects 13:183-188.

- 199lb: On the African species of Aglymbus Sharp 1882 (Coleoptera Dytiscidae), with a new species from Ethiopia. — Trop. Zool. 4:75-80.

1992a: A revision of the East African Nebrioporus abyssinicus group (Coleoptera, Dytiscidae). Entomol. Fennica 3:81-93.

- 1992b: A revision of Afrotropical Agabus Leach (Coleoptera, Dytiscidae), and the evolution of tropicoalpine super specialists. - Syst. Entomol. 17:155-179.

Nilsson, A. N. \& Angus, R. B. 1992: A reclassification of the Deronectes-group of gentera (Coleoptera, Dyliscidae) based on a phylogenetic study. - Entomol. Scand. 23:275-288.

Nilsson, A. N. \& Persson, S. 1990: Dimorphism of the metasternal wing in Agabus raffrayi and A. labiatus (Coleoptera: Dytiscidae) questioned. - Aquatic Insects 12:135-144.

Olivier, A. G. 1795: Entomologie ou histoire naturelle des Insectes. Vol. 3. Coléoptères 40. - Paris.

Omer-Cooper, J. 1930: Dr. Hugh Scott's expedition to Abyssinia. - A preliminary investigation of the freshwater fauna of Abyssinia. - Proc. Zool. Soc. London (4) 59(1):195-207+15 pls.

- 1931: Report on the Dytiscidae (Coleoptera), Mr. Omer-Cooper's investigation of the Abyssinian fresh waters (Hugh Scott Expedition). - Proc. Zool. Soc. London 1931:751-801.

- 1954: A new species of Yola (Col., Dytiscidae) from Somaliland, — Entomologist's Mon. Mag. 90:212-213.

- 1957: Dytiscidae (Coleoptera) collected in the Transvaal (Rhodes University Expedition 1948). - Mem. Entomol. Soc. S. Africa 5:1-90.

- 1958: Dytiscidae from Nyasaland and S. Rhodesia. 4. Vatellinae, Methlinae, and Hydroporinac, Hyphydrini. — J. Entomol. Soc, S. Africa 21:249-260.

1959: Dytiscidae from Nyasaland and Southern Rhodesia. 5. Hydroporinae, Bidessini. - J. Entomol. Soc. S. Africa 22:108-137. 
- 1965a: Chapter 2. Coleoptera: Dytiscidae. A review of the Dytiscidae of Southem Africa being the results of the Lund University Expedition 1950-1951, with which are incorporated all other records known to the author. — S. Afr. Animal Life 11:59-214.

- 1965b: Dytiscidae (Coleoptera) of Nyasaland and Southem Rhodesia. IX. Dytiscinae: Eretini, Hydaticini, Thermonectini. — J. Entomol. Soc. S. Africa 28:92106.

- 1970a: Three new species of African Peschetius Guignot (Coleoptera: Dytiscidae). - Proc. R. Entomol. Soc. London (B) 39:85-88.

- 1970b: New and little known species of African Laccophilus (Coleoptera: Dytiscidae). - J. Entomol. Soc. S. Africa 33:285-294.

- 1970c: A contribution to the study of the African species of the genus Neptostemus Shp. (Coleoptera: Dytiscidae) with the descriptions of four new species. — J. Entomol. Soc. S. Africa 33:63-79.

- 1974: The species of Bidessus Sharp (Coleoptera: Dytiscidae) of Africa south of the Sahara including Madagascar. 1. - J. Entomol. Soc. S. Africa 37:305314.

- 1979: The species of Bidessus Sharp (Coleoptera: Dytiscidae) of Africa south of the Sahara including Madagascar. 2. — J. Entomol. Soc. S. Africa 42:197216.

Pederzani, F. 1988: Dytiscidae collected in Zambia and description of Hyphydrus fluviatilis n.sp. and Hyphydrus zambiensis n.sp. (Coleoptera Dytiscidae). Atti I.R. Accad. Roveret. Sci.(B) 26(1986): 103-118.

Perris, M. 1864: Description de quelques espèces nouvelles de Coléoptères, et notes diverses. - Ann. Soc. Entomol. Fr. (4) 4:275-280.

Peschet, R. 1916: Description dún Hyphydrus nouveaux d'Abyssinie (Col. Dytiscidae). - Bull. Soc. Entomol. Fr. 1916:202-203.

- 1922: Dytiscidae et Gyrinidae recueillis par le marquis S. Patrizi en Afrique orientale anglaise. - Ann. Mus. Civ. Stor. Nat. Giacomo Doria 9:374-377.

Peyerimhoff, P. de. 1931: Mission scientifique du Hoggar, Coléoptères. - Mém. Soc. Hist. Nat. Afr. N. 2:1-173.

Raffray, A. 1885: Note sur la dispersion géographique des Coléoptères en Abyssinie et descriptions d'espéces nouvelles. - Ann. Soc. Entomol. Fr. (6) 5:293-326+ pl. 6.

Ragusa, E. 1887: Coleotteri nuovi o poco consciuti della Sicilia. - Naturalista Sicil. 6:43.

Régimbart, M. 1887: Dytiscidae et Gyrinidae collectés dans le royaume de Scioa (Abyssinie), par Mr. le Dr. Ragazzi en 1885. - Ann. Mus. Civ. Stor. Nat. Giacomo Doria (2) 4:636-641.

- 1889: Dytiscidae et Gyrinidae nouveaux ou rares de la collection Musée Royal de Leyde. - Notes Leyden Mus. 11:51-63.

- 1894: Voyage de M.E. Simon dans l'Afrique australe (Décembre - Mars 1893). Haliplidae, Dytiscidae \& Gyrinidae. - Ann. Soc. Entomol. Fr. 63:227-240.
- 1895a: Revision des Dytiscidae et Gyrinidae d'Afrique, Madagascar et Iles voisines. - Mém. Soc. R. Entomol. Belg. 4:1-244.

- 1895b: Dytiscidae et Gyrinidae. 11. Esplorazione del Giuba e dei suoi affluenti compiuta dal Cap. V. Bottego. - Ann. Mus. Civ. Stor. Nat. Giacomo Doria 35:185194.

- 1899: Diagnoses d'espèces nouvelles de Dytiscidae de la Région Malgache. - Bull. Soc. Entomol. Fr. 1899:371-374.

- 1903: Coléoptères aquatiques (Haliplidae, Dytiscidae, Gyrinidae et Hydrophilidae) recueillis dans le sud de Madagascar par M. Ch. Alluaud. - Ann. Soc. Entomol. Fr. 72:1-51.

- 1904: Escursione del dott. Achille Tellini nell'Eritrea, Ottobre 1902 - Febbraio 1903. Coleotteri Acquatici. — Udine, privately printed.

- 1905: Materiali per lo studio della fauna Eritrea raccolti nel 1901-03 dal Dr. A. Andreini tenente medico. Boll. Soc. Entomol. ital. 36(1904):201-226.

- 1906: Voyage de M. Ch. Alluaud dans l'Afrique Orientale. Dytiscidae, Gyrinidae, Hydrophilidae. Ann. Soc. Entomol. Fr. 75:235-278.

- 1907: Collections publiées par M. Maurice De Rothschild dans l'Afrique orientale. Insectes Coléoptères: Dytiscides et Hydrophilides, - Bull. Mus. Nat. Hist. Nat. Paris 13:126-128.

- 1908: Coleoptera. Dytiscidae, Gyrinidae, Hydrophilidae, - In: Sjöstedt, Y. (ed.), Wissenschaftliche Ergebnisse der schwedischen zoologischen Expedition nach dem Kilimandjaro, dem Meru und der Umgebenden Massaisteppen Deutsch-Ostafrikas 1905-1906. 7(1). Uppsala.

- 1922: Dytiscides, gyrinides et hydrophilides. — Résult. Sci. Voy. Baron M. de Rothschild Ethiopie 2:528-536.

Reiche, L. 1850: Entomologie. - In: Ferret, A. \& Galinier (eds.), Voyage en Abyssinie 1839-43, Vol. 3:259-419 +13 pl. Paris $1847-50$.

Rocchi, S. 1975a: Coleotteri Ditiscidi dell'Africa orientale, - Monitore Zool. Ital. N.S. Suppl. 6:45-56.

- 1975b: Nota sistematica sul Potamonectes tellinii (Régimbart, 1904) (Coleoptera Dytiscidae). - Monitore Zool. Ital. N.S. Suppl. 6:269-274.

- 1984: Insects of the Yemen Arab Republic. Coleoptera: Fam. Haliplidae, Dytiscidae, Gyrinidae. - Fauna of Saudi Arabia 6:444-450.

Rossi, P: 1790-1792. Fauna Etrusca. -- Liburnii.

Schaum, H. R. 1864: Die Egyptischen Dytisciden. - Berl. Entomol. Zeitung. 8:105-108.

Scott, H. 1952: Journey to the Gughé Highlands (Southern Ethiopia), 1948-9; biogeographical research at high altitudes. — Proc. Linn. Soc. London 163(2):85-185 +1 map + pls. $3-28$.

- 1958: Biogeographical research in High Simien (Northern Ethiopia) 1952-53. - Proc. Linn. Soc. London 170(1):1-91 + pls. 1-17.

Sharp, D. 1882: On aquatic carnivorous Coleoptera or Dytiscidae. - Sci. Trans. R. Dubl. Soc. (2) 2:179$1003+$ pl. 6-18. 
- 1901: Water-beetles (Dytiscidae \& Hydrophilidae) of the Swedish Zoological expedition to Egypt and the White Nile. - In: Jägerskiöld, L. A. (ed.), Res. Swedish Zool. Exped. to Egypt and the White Nile 10:1-10.

Walker, F. 1871: List of Coleoptera collected by J.K. Lord... in Egypt, Arabia and near the African shore of the Red Sea. - London, $19 \mathrm{pp}$.

Wallengren, H. D. J. 1881: Coleoptera Transvaaliensis. Bidrag till kännedomen om Transvall landets i SydAfrika Coleoptera fauna. - Entomol. Tidskr. 1:9-22.

Wewalka, G. 1974: Systematische und faunistische Bemerkungen zu einiger Paläarktischen dytisciden (Coleoptera). - Koleopterol. Rundschau 51:105-113.

- 1980: Revision der afrikanischen Gattung Heterhydrus Fairm. (Coleoptera, Dytiscidae). - Ann. Hist.-Nat. Mus. Nat. Hung. 72:97-101.

- 1981: Die Arten der Gattung Canthyporus Zimmermann aus Zentral-Afrika mit Beschreibung eiener neuen Art (Dytiscidae, Col.). - Koleopterol. Rundschau 55:57-64.

-_ 1982: Neue Copelatini aus Madagaskar und Afrika (Dytiscidae, Col.). — Koleopterol. Rundschau 56:127133.

- 1989: Systematic and faunistic notes on Noteridae and Dytiscidae of the Near East (Coleoptera). - Koleopterol. Rundschau 59:143-152.
Wewalka, G. \& Nilsson, A. N. 1990: A new species of Agabus Leach (Coleoptera, Dytiscidae) from the highlands of Ethiopia. — Trop. Zool. 3:151-157.

Wollaston, T. V. 1867: Coleoptera Hesperidum, being an enumeration of the coleopterous insects of the Cape Verde archipelago. - London, $285 \mathrm{pp}$.

Zimmermann, A. 1919 (1917): Die Schwimmkäfer des Deutschen Entom. Mus. zur Berlin-Dahlem. - Arch. Naturgesch. 83(12):107-249.

- 1920: Bemerkenswerte Neuerwerbungen des Zoolog. Museums in Hamburg: Haliplidae, Dytiscidae und Gyrinidae. - Entomol. Bl. Biol. Syst. Käfer 16:224234.

- 1926: Schwimmkäfer-Material aus Deutsch-OstAfrika, gesammelt von Geh. Regieringsrat Methner in den Jahren 1909-1916. — Entomol. BI. Biol. Syst. Käfer 22:18-31.

- 1927: Bemerkungen über einige Schwimmkäfer des Senckenberg-Museums nebst drei Neubeschreibungen. - Senckenbergiana 9:32-38.

1928: Neuer Beitrag zur Kenntnis der Schwimmkäfer. -Wiener Entomol. Zeitung. 44:165-187.

Received 26.X.1990

Table 1. Provincial records and altitudinal ranges ( $m$ a.s.I.) of the Ethiopian species of Dytiscidae. See Fig. 7 for abbreviations of provinces. ${ }^{*}=$ endemic to Ethiopia.

"Canthyporus loeffleri: 3500: GD.

${ }^{*} \mathrm{C}$. hynesi: 2850: $\mathrm{SH}$.

Methles cribratellus: 565-2350: SH, IL, KA, GG.

M. spinosus: $565: \mathrm{GG}$.

Derovatellus bisignatus: IL.

*Uvarus andreinii: 1500-2600: ER, GD, GO, SH, IL, AR.

U. peringueyi: 1450: AR, KA.

U. captiosus: $2400: \mathrm{SH}$, IL.

U. devroyei: 1720: SH, IL, KA.

U. miser. 1100: $\mathrm{SH}$.

Pseuduvarus vitticollis: 1720: IL, KA.

Hydroglyphus infirmus: 1100-2500: ER, GD, GO, WO, $\mathrm{SH}, \mathrm{HA}, \mathrm{AR}, \mathrm{BA}, \mathrm{SI}$.

H. confusus: 1000-2300: ER, SH, HA, AR.

H. geminodes: 700-2300: ER, SH, IL, KA, GG.

H. shalensis: 950-1500: SH, SI.

H. aethiopicus: 1100-2300: SH, KA, SI.

${ }^{\star} H$. milkoi: 1500-3100: GO, WO, SH, AR, BA.

H. pentagrammus: SH, IL.

H. flavoguttatus: $2400: \mathrm{SH}$.

H. major. ER.

$H$. angularis: ER.

H. angulolineatus: $1350: \mathrm{SH}, \mathrm{SI}$.

${ }^{*} H$. perssoni: 2800: BA.

H. sordidus: 1200-3100: ER, SH, AR, BA, GG, SI.

"H. fufai: 2069-3100: GO, SH, IL, AR, BA.

H. zanzibarensis: 450-1800: GO, IL, GG, SI.

H. signatellus: $1500: \mathrm{SH}, \mathrm{HA}$.
Bidessus sharpi: IL.

B. complicatus: $1700: \mathrm{SH}$.

B. cacozelus: $1800-2700: \mathrm{SH}$.

${ }^{*} B$. perssoni: 3100: AR.

B. ovoideus: $1500-2600$ : GO, SH, AR, KA.

B. toumodiensis: 1800: GO.

B. sodalis: $2400: \mathrm{SH}$.

B. rothschildi: 1000-2300: SH, HA, BA, KA.

${ }^{*} B$. muluensis: 2100-2950: GD, SH, AR.

Leiodytes hieroglyphicus: 1800: IL, AR.

L. evanescens: $\mathrm{HA}$.

Clypeodytes cribrosus: 1800 : GO.

C. meridionalis: 1700-2300: ER, SH, AR, KA.

Yolina insignis: ER.

Yola tuberculata: 2400: SH.

Y. darfurensis: GG.

Y. frontalis: 1800-2550: ER, SH, AR.

Y. enigmatica: ER.

Hydrovatus reticuliceps: 1450-1800: GO, KA.

H. liberatus: 1800: GO.

H. sordidus: $950: \mathrm{SH}$.

H. badius: 565-2300: SH, AR, GG, SI.

H. absonus: 1800 : GO.

H. bredoi: 1720: KA.

H. cuspidatus: ER.

H. aristidis: IL.

H. procus: $1720-1800$ : GO, KA.

H. glomeratus: $1800: \mathrm{SH}$. 
H. simoni: 1800: GO.

H. spissicornis: ER.

H. regimbarti: 1800: $\mathrm{SH}$.

H. difformis: 1600-2300: SH, IL, SI.

H. pescheti: 1500-2100: SH, AR, KA.

H. villiersi: 565-2400: SH, GG.

H. nigricans: 1600 : SI.

H. compactus: $2400: \mathrm{SH}$.

H. oblongipennis: 2400: SH, IL.

$H$. badeni: 2100: AR.

${ }^{*} H$. mundus: 1650: $\mathrm{SH}$.

H. laticornis: 585-1720: SH, KA, GG, SI.

$H$. longicornis: 1500-2300: SH, AR.

*Herophydrus muticus: 1650-3100: ER, TI, SH, AR, BA.

${ }^{*} H$. quadrilineatus: 2069-3100: SH, AR.

H. guineensis: 1350-2300: GO, SH, SI.

H. sobrinus: $1650-2100: \mathrm{SH}$.

H. pallidus: 1600-2300: SH, SI.

$H$. inquinatus: $2100: \mathrm{SH}$.

H. erythraeus: 1800-2100: ER, SH, AR.

Heterhydrus sudanensis: IL.

Hyphydrus parvicollis: 2400: SH, IL.

H. grandis: ER, IL.

${ }^{*} H$. fuscus: 2400-2700: SH, GG.

${ }^{*} H$. silfverbergi: ER, KA.

$H$. nigrovittatus: GD.

H. cycloides: 1450-1800: GO, KA.

H. signatus: 1500-2600: ER, GO, SH, HA, AR, BA, $\mathrm{KA}, \mathrm{SI}$.

H. pictus: ER, WO.

H. puncticollis: 2100-3100: ER, SH, AR, BA.

${ }^{*} H$. abyssinicus: HA.

$H$. maculatus: ER.

H. impressus: 480-2300: SH, AR, GG.

Peschetius carinipennis: IL.

Nebrioporus abyssinicus: 2300-3100: ER, WO, SH, IL, AR.

${ }^{\star} N$. cooperi: $2350-3100$ : ER, GD, SH, AR, BA.

${ }^{*}$ N. scotti: 2400: GD, SH.

${ }^{*} N$. tellinii: 2200-3200: ER, GD, SH, AR.

Copelatus erichsoni: 1450-2500: ER, GO, SH, AR, HA, IL, KA.

C. atrosulcatus: 1450-2500: SH, AR, IL, KA, GG, SI.

${ }^{*} C$. hararensis: $\mathrm{HA}$.

C. edax:?.

C. bottegoi: AR.

${ }^{*}$ C. andreinii: 1450-1800: ER, GO, KA, GG.

C. aethiopicus: 1600-2500: GO, SH, AR, IL, KA, SI.

C. pulchellus: 1000: ER, SH, IL.

C. scytalotus: IL.

C. latus: IL.

C. waltoni: 1450-1800: GO, KA.

C. fontanus: IL.

${ }^{*}$ C. ragazzii: 2100-3100: $\mathrm{SH}, \mathrm{AR}$.

C. decemsulcatus: IL.

C. parallelipipedus: 1700: KA.

C. pumilus: $2400: \mathrm{SH}$.

${ }^{*}$ C. parisii: ER.

Aglymbus gestroi: ER.
${ }^{*}$ A. brevicornis: 2500 : GD, SH.

${ }^{*}$ A. multistriatus: 1750 : KA.

${ }^{*}$ Agabus discicollis: 3170-4000: GD, WO.

*A. ambulator: 2900-3750: GD, GO, WO, SH, AR, SI.

*A. loeffleri: 3200-4000: AR, BA.

*A. raffrayi: 2100-3200: GD, GO, SH, AR, BA, SI.

*A. pallidus: 2250-4000: GD, SH, AR, BA, GG.

${ }^{*}$ A. ragazzii: 2250-2600: SH, KA.

*A. perssoni: 2350-3450: GD, SH, AR, BA.

*A. crypticoides: 2350-2500: AR.

*A. abessinicus: 2500: HA, BA.

${ }^{*}$ A. galamensis: 3100: AR.

Rhantus includens: 2700: ER, SH.

${ }^{*} R$. longulus: 1650-3100: SH, AR, BA, KA.

R. capensis: 1800-3100: ER, SH, AR.

Laccophilus pictipennis: ?.

L. laeticulus: 1800: GO.

L. flavopictus: $1600-1800: \mathrm{GO}, \mathrm{SH}, \mathrm{SI}$.

* L. grammicus: 1800-2200: ER, SH.

* L. quindecimvittatus: 1450-2700: GO, SH, AR, KA, GG.

L. contiro: 2100: AR.

L. adjutor: $\mathrm{SH}$.

L. remex: IL.

L. vitshumbii: 1450-2350: ER, GO, SH, AR, KA.

L. evanescens: 400: GG.

L. modestus: 1800: GO, IL.

L. torquatus: KA.

L. simplicistriatus: 1500-2350: GO, SH, AR, SI.

L. taeniolatus: 950-2500: SH, AR, IL.

L. inornatus: 1800 : GO, IL.

L. pellucidus: $1500-2300: \mathrm{SH}$.

Philodytes umbrinus: 480-2400: SH, GG.

Neptosternus meridianus: 1100: $\mathrm{SH}$.

N. sombuicus: IL.

Eretes sticticus: 700-1500: ER, SH, IL, KA, GG, SI.

Hydaticus jeanneli: 1700-2400: SH, KA.

H. exclamationis: 1700-2100: GO, SH, KA.

H. bivittatus: 1800 : GO.

H. flavolineatus: 1130-2500: ER, SH, AR, SI.

H. paganus: KA.

H. dregei: ER.

H. leander: 1650-1800: GO, IL.

${ }^{*} H$. basicollis: 950-2400: SH, SI.

H. servillianus: 460 : $\mathrm{GG}$.

H. matruelis: 1130-2400: GO, SH, AR, IL, KA, SI.

H. dorsiger: 1650-2400: GO, SH, KA.

${ }^{*} H$. abyssinicus: $2300-3100: \mathrm{SH}, \mathrm{AR}, \mathrm{KA}$.

H. galla: 1450-2600: ER, GO, SH, AR, BA, IL, KA, SI. H. caffer. 1900: ER, KA, SI.

Rhantaticus congestus: 700-2300: ER, SH, KA.

Aethionectes apicalis: 1550: SI.

Cybister vulneratus: 1600-1700: SH, KA, SI.

C. pinguis: IL.

C. marginicollis: 1700: KA.

C. senegalensis: SI.

C. reichei: IL.

C. tripunctatus: 950-2300: ER, SH, SI.

C. gschwendtneri: ER.

C. cephalotes: ER. 